\section{THE PHENOMENON OF ROMAN REPUBLICAN COINAGE IN PRE-ROMAN DACIA. A REXAMINATION OF THE EVIDENCE}

\begin{abstract}
This article offers a re-examination of the phenomenon of Roman Republican coinage during the pre-Roman period in Carpathian region. It is argued that by compiling the evidence into a multifaceted database, new insights are gained on the explanation of the currency in pre-Roman Dacia. Furthermore, the study employs statistical methods in an interdisciplinary approach to a better pinpoint the chronological point of entry for Republican denarii into the region. Due to the absence of archaeological context in many cases, coin hoards are the main focus of data collection.
\end{abstract}

Keywords: Roman republican coinage, pre-Roman Dacia, coin hoards, coin copies, trade routes

\section{INTRODUCTION}

$\mathbf{T}$

he aim of the present research is to study the emergence of the Romantype coin on the territory inhabited mostly by north Danubian GetoDacian tribes, generally called Dacians. The term 'Dacians' is used without ethnic implications and the term 'Dacia' refers to the CarpathianDanubian-Pontic territory not to a state that would have included all this area. A component of the history of this territory from the period before the Roman conquest is the presence in the archaeological discovers of the Roman coins. The explanations are varied and it often happens for theories to contradict.

From historical sources, it is not possible to form a clear image on Dacia: there are very few reliable sources available in order to recreate an exact structure of the Dacian society. It is not possible to know for sure if the Geto-Dacian society was uniform, homogenous. It is known for a fact that Burebista was a strong leader in his times, 82-44 BC, and that represented a constant danger for Greek towns. ${ }^{1}$ Burebista was the only man capable, even though for a short period of time, to unite under his sceptre all Geto-Dacian tribes and to kneel the neighbouring communities from Dacian's boundaries, to command the cities from the West coast of Pontus Euxinus: from Olbia to Apollonia. A wide period between Burebista and the Roman conquest is unclear, the only literary source being Jordanes's List.

The objective conditions of development for the Geto-Dacian society

\section{Marius Grigore Stan}

DOI: http://dx.doi.org/10.14795/j.v1i4.90

ISSN $2360-266 \mathrm{X}$

ISSN-L 2360 - 266X

\footnotetext{
1 CRIŞAN 1979, 490.
} 
from the $1^{\text {st }}$ century $B C$ imposed a new form of political organization ${ }^{2}$. However, Dacians were far from having a common consciousness, a common market or a common administrative apparatus.

Between the $4^{\text {th }}$ century $B C$ and the end of the $1^{\text {st }}$ century $B C$ the geographic area of Dacia, but also the southern neighbouring areas are well supplied with coins, usually coins of Greek cities which interacted with the local with populations for commercial reasons. Sometimes in the $1^{\text {st }}$ century $\mathrm{BC}$, the Roman denarius appeared and managed to become in a short time the main currecncy in the area under study. The moment when the denarius is first used in Dacia is not known.

This study aims to analyse when and how the Roman Republican coin reached Dacia.

\section{COINAGE IN PRE-ROMAN DACIA}

Before the advent of the coin itself, historians agree that there were different items that were used in commercial exchanges, the value being commonly recognized by both parties. Such objects are not missing from this territory either, usually being metallic objects: bronze axes, arrowheads ${ }^{3}$.

Distributed since the beginning especially in the area of the Black Sea, the first forms of coins were associated with Greek colonies from the Black Sea coast. A second group of items that have the function of money, are dolphins or small fishes made out of bronze $\mathrm{e}^{4}$, these being concentrated on the Black Sea coast, close to the Greek city of Olbia. 'Arrowheads' date from the first part of the 4 th century BC, while dolphins towards the end of this century ${ }^{5}$.

The Roman Republican denarius is the coinage to be studied here. The denarius appears in Dacia and becomes the main currency in a short period. According to studies, the Roman denarii will be listed in the silver Roman mint towards the end of the $3^{\text {rd }}$ century ${ }^{6}$. It is the most widespread coin in the ancient world, long before the era of the Roman Empire.

The first problem regarding the presence of denarii in Dacia is a chronological one. Unfortunately, the situation is not clear enough because of the hoards' structure but also because of the incomplete information. It is not possible to determine the main phases of entry and circulation of the denarius. This paper will limit at analysing the coin hoards that contain Roman Republican coins, together with other coins of the Greek cities in general, only from the territory of modern Romania. Also, there won't be analyse the isolated discovery of Roman Republican coins, thus the study/ hypothesis being elaborated strictly on the research of coin hoards.

Firstly, it is important to observe the reason why denarii appeared in this area, then to observe based on statistical information or maps of coin hoards that contain denarii, the precise moment denarii entered pre-Roman Dacia and, finally, to analyse the function these have in the Dacian society. The latter will not be a central theme of this 2 CRIŞAN 1979, 491.

3 MIHĂILESCU-BÂRLIBA 1990, 36-8, 181.

4 SIMMEL 1990, 144-145.

5 MIHĂILESCU-BÂRLIBA 1990, 38.

6 CRAWFORD 1974. paper but it represents a good starting point for further research.

In order to answer the first question, the context in which denarii were inserted in this area must be analysed. Literary sources certify that in Lower Danube and Thrace in the Hellenistic period there was a great need for precious metals ${ }^{7}$.

In addition, archaeological sources and coin finds in Dacia and Thrace certify a long time use on a large scale until the $1^{\text {st }}$ century $\mathrm{BC}$ of silver coins. These are the tetra drachmae of Alexandre III, Philip II (together with imitations in large quantities) and Lysimachus, Geto-Dacian tetra drachmae, Macedonia Prima and Thasos (imitations in very large quantities), drachmae from Dyrrachium and Apollonia, these two being dominated between the $4^{\text {th }}$ and $1^{\text {st }}$ century $\mathrm{BC}$ in this region, both being found in quantities considered to be imitated. ${ }^{8}$ Large part of these coins have the origins outside the area of Lower Danube, the coins of Philip II and his successors origin from Macedonia or South Thrace, the coins Macedonia Prima and Thasos, together with their imitations come probably from the same rea, and coins from Dyrachium and West Apollonia. Geto-Dacian tetra drachmae come, most likely, from Dacia, possibly in a short period, somewhere between the $2^{\text {nd }}$ and $3^{\text {rd }}$ century BC. ${ }^{9}$

The most important and numerous currency in Dacia is the drachma from the cities of Apollonia and Dyrrachium. These coins are minted at the end of the 3rd century $\mathrm{BC}$ until the early 50 BC. Dyrrachium coins being more frequently found than those of Apollonia. In 1955, J. Winkler gives a relative account: 1841 drachmae of Dyrrachium compared with 293 of Apollonia ${ }^{10}$.

The need for silver as currency trading in this geographical area is explained by archaeological material found in this area, but also by ancient writings ${ }^{11}$. It is also known that the Hellenistic world extensively used silver as a means of trade, and the region discussed herein, is under Hellenistic influence.

In such a context, Roman Republican denarii appears in pre-Roman Dacia. Therefore, the need for the denarius is explained by the constant need for silver of the populations from the Carpatho-Danubian area, probably used for trade in significant quantities.

Even though the supply in this area of the Roman Republican currency is a long debated topic, it is very difficult to determine a pattern of supply. It is unclear how the coins reached Dacia, the problem being further complicated by the discovery of a large number of denarii imitations, probably imitations made in Dacia ${ }^{12}$.

Even though this is very unlikely, due to the inexact information there is in this segment, it is possible to observe some sort of coin road. However, it is not possible to determine the moment (period) when the coin enters Dacia. The relations between the coins before the entrance of denarii in Dacia and the Roman Republican denarius are not easy to investigate. It involves too many variables, an aspect
7 Polybius IV, 46, 3.
8 CRAWFORD 1977, 118.
9 CRAWFORD 1977, 118.
10 WINKLER 1955, 40-41.
11 Polybius, IV, 38.
12 LOCKYEAR 1996, 401. 
highlighted in this paper.

Firstly, the analysis of trade routes, both naval and land ones, may offer an idea of possible ways of entry for the denarius in Dacia. Although this is highly unlikely due to inaccurate information that we have in this particular field, we may even see some itineraries for coins, but will not be possible to determine the moment (period) when this currency enters Dacia.

\section{TRADE ROUTES FROM AND TO PRE-ROMAN} DACIA

The development of ancient trade, beyond the political and economic conditions required, depended largely on the situation of trade routes, either sea or land. The existing situation and progress in navigation between the 4th and 1st century $\mathrm{BC}$ had an important influence in creating new connections between regions at considerable distances. The weight, and the large dimensions at the Roman ships, compared to the Hellenistic ones led to the inevitable progress of trade relations especially in the Roman period. ${ }^{13}$ There were two major maritime routes between Dacia and the Mediterranean world. These were up the Adriatic into Dalmatia, and the Aegean leading into the Black Sea ${ }^{14}$ Thus, we can assume that much of the trade was done through areas where Hellenistic and Oriental influence were dominant.

An interesting mutation occured in commercial markets when there are merchants from different regions of the ancient world. Thus, after the sporadic and shy occurrence of Italics in the Aegean Sea Basin, an area in which the monopoly of trade relations was held by Greeks and Orientals, from the $3^{\text {rd }}$ century and the middle of the $2^{\text {nd }}$ century $\mathrm{BC}$, following by the end of the Republican era, can be observed a massive movement of Romans in the East ${ }^{15}$.

In the period of maximum expansion of the Romans in the Orient, from the wars with Mithradates until the end of the 1st century BC, Italics are present in all Eastern regions, going beyond also of Hellenistic areas. Regarding the numerous Roman communities and other individuals who were running businesses, it is important to make an observation: the largest contribution of cives Romani came from Italian areas, Greek at origins, who received citizenship due to the laws from 89 and 88 BC. ${ }^{16}$ It was the strong participation of the Italics in trade on the southern areas of the Apennine Peninsula that explains both Romans' presence in the trade around Pontus Euxinus, as well as their contact with the local population. Polybius states that with the victory of Rome over Macedonia in the Battle of Pydna, 168 $\mathrm{BC}$, the Romans conquered the entire Mediterranean world, so, trade was controlled by them, control that reached also the Balkan Peninsula. Military superiority, new maritime technologies and an offensive diplomacy, allowed the Romans to transport larger amounts of commercial products than in the past and thus managing to impose in the Mediterranean world, helped also by the constant disagreements between the Greek cities that took large majority of legislation. ${ }^{17}$

13 ROUGE 1966, 78.

14 GLODARIU 1976, 18

15 GLODARIU 1976, 20

16 GLODARIU 1976, 20; HATZFELD 1919, 238-256.

17 ROUGE 1966, 77.
According to W.V. Harris, the states controlled by the political power of Rome, the so-called client states, were part of the 'Informal Empire'18 and not controlled by the central administration from Rome. Dacia could have been in a situation to be controlled by Rome, or at least influenced by their politics, expect during Burebista, who stands out as an independent ruler. The external politics of Rome had direct consequences on crafts development and commerce in the ancient world.

The production centres of various Hellenistic and Roman goods discovered in Dacia, the nature of these goods and the existing transport possibilities in antiquity may be determinative in establishing trade routes followed by the Greco-Roman merchants to reach the Carpatho-Danubian lands. These roads are, most likely also the ways in which Roman Republican denarii get into this space, through merchants. The centres of origin of different categories of Hellenistic and Roman goods were largely in Pontus-Euxinus, on the eastern coast of the Adriatic Sea, in the southern part of Italy and in its northern area ${ }^{19}$. For certain categories of products, especially those transported in amphorae (wine, olive oil, etc.), the safest and most profitable trade route was by sea and river, such a trade being recommended especially for product safety and for reduced expenses in case of long distances.

Wines and Greek or oils, transported in amphorae, were aboard the ships that went out of Rhodes, Cnidos, Coş, Thasos, or other known centres on the Pontus-Euxinus coast $^{20}$. It is difficult to present details of the routes of ships departing from different production centres. In general, movements in the Aegean Sea was made in the southnorth direction. ${ }^{21}$ The sea, used almost exclusively for the transport of amphorae with wine and oils became safe after the disappearance of pirates carried out under the leadership of Pompey in $67 \mathrm{BC}^{22}$, action that included the coasts of the Aegean Sea and the Black Sea. The intervention of Pompeius has greatly contributed to increasing the trade connections in the Carpatho-Danubian provinces with Greek and Romanian centres in the second half of the 1st century $\mathrm{BC}^{23}$. From Pontus-Euxinus commercial vessels entered the Danube and its main tributaries. Danube was widely used as a maritime way for wine merchants and oils that come from the Hellenistic world, as it looks from the discoveries of amphorae along the Danube. ${ }^{24}$ From the Danube, ships transporting commercial goods could easily continue on its main tributaries, on distances varying depending on the season (or the navigation possibilities of each river).

Reportedly, ancient authors, most of the rivers that flooded in Danube were navigable by large distances. Pliny says about the Danube that at its flood into Illyria, the flow increased very much due to the 60 rivers that flooded into the Danube, half of them being navigable. ${ }^{25}$ Another ancient author, Strabo mentions the course of Mureş River, river

\footnotetext{
18 HARRIS 2008, 531.

19 GLODARIU 1976, 108.

20 GLODARIU 1976, 111.

21 GLODARIU 1976, 111

22 CRAWFORD 1977, 121.

23 GLODARIU 1976, 111.

24 GLODARIU 1976, 111

25 Plinius IV, 12, 79
} 


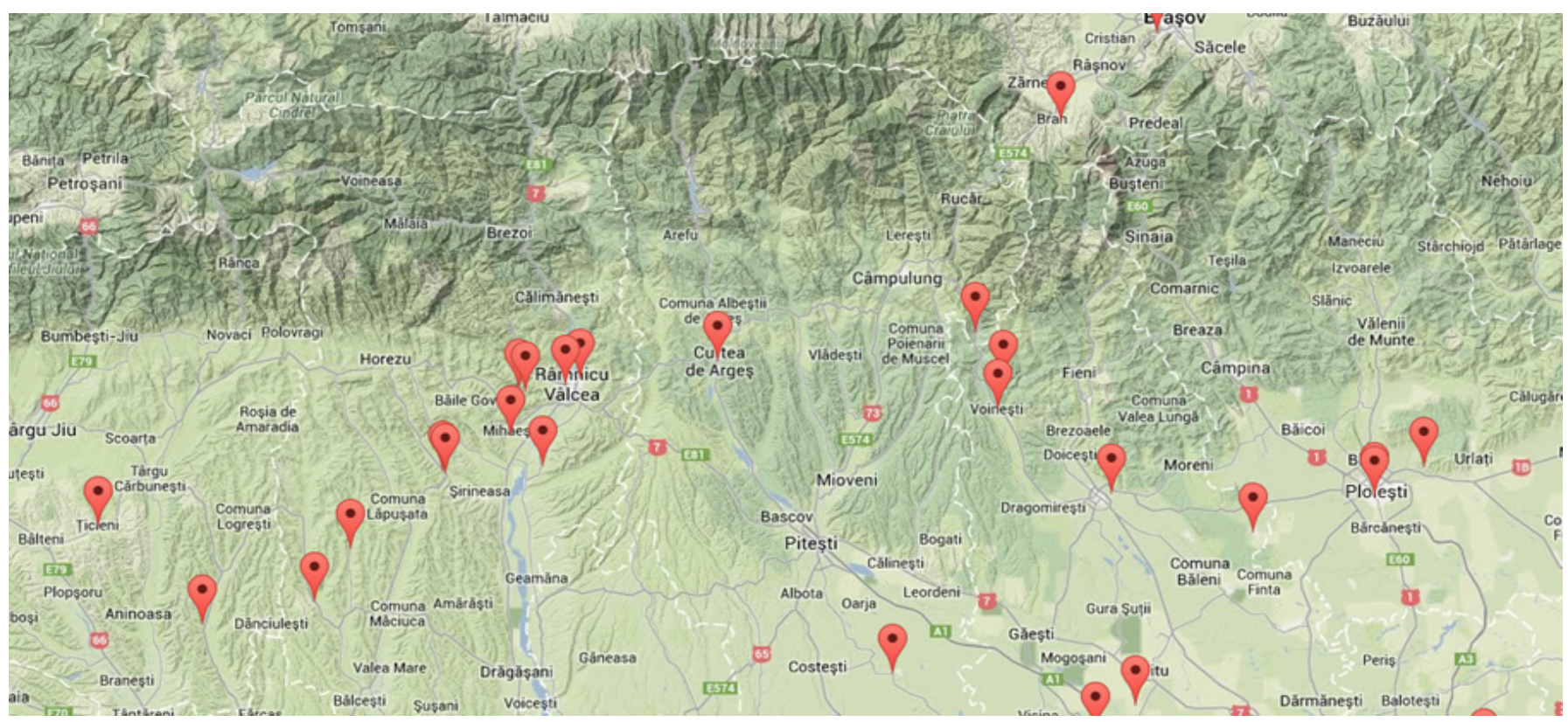

Map 1. Coin hoards distribution, whitin Carpathian passes. ${ }^{26}$

used by the Romans for making war supplies. ${ }^{27}$ Based on the amphora's finds, I. Glodariu has considered that rivers such as Prut, Siret, Ialomiţa, Argeş, Mureş were sailable. ${ }^{28}$ As it can be seen, the Olt River was not not sailable until the $1^{\text {st }}$ century $\mathrm{AD}$, when works of cleaning and broadening the gorge took place, with the purpose of making it a navigable trade route. ${ }^{29}$ I. Glodariu has suggested that, more likely, the road that started at the mouth of the Olt River and went on his thread, curving west to the junction with Lotru River, then follow its course and continue with the road that descends in Transylvania on the springs of Sadu River. In support of this view, there are the finds of Thasos tetradrachmas at the springs of Sadu River, of a Koson coin in Brezoi and the use of the road mentioned throughout the late Middle Ages to modern times, until the necessary arrangements were made again for the circulation through the Olt Gorge. Personally, I think that the arguments are not convincing, that the author may be right, but it is also possible to have two routes, one that passes through the mountains of Olt, and the second one that is mentioned by Glodariu. Olt River also seems to be navigable, especially because of the many coin hoards found in the mountains at the entrance of the river, in Mihăeşti, Luncă, Ocniţa, Goranu, Râmnicu Vâlcea and Cremenari (Map 1).

It is also true that they are ahead of the turning mentioned by I. Glodariu, on Lotru. Based on available evidence, it is possible to say that the transition was made on the springs of Sadu and Brezoi, Jiu River was more likely to be used.

Roman and Greek merchants, once arrived in Dacia, used the existing roads in most cases along large rivers, as the main commercial route of Dacia was the Danube, all

26 http://tezauremonetare.ro/maps?utf8=\%E2\%9C\%93\&q\%5Blocation cont $\% 5 \mathrm{D}=\& \mathrm{q} \% 5 \mathrm{Bperiod}$ cont $\% 5 \mathrm{D}=$ republican $\& \mathrm{q} \% 5 \mathrm{~B}$ province cont $\% 5 \mathrm{D}=\& \mathrm{q} \% 5 \mathrm{Broad}$ true $\% 5 \mathrm{D}=0 \& \mathrm{q} \% 5 \mathrm{Broad}$ false $\% 5 \mathrm{D}=0 \&$ commit $=$ Search

27 Strabo VII, 3, 13

28 GLODARIU 1976, 111.

29 GLODARIU 1976, 117. major roads starting from this river. In general, the roads could be established, based on the geographical layout of the discoveries of Hellenistic and Roman products and also of Greek and Roman coins.

The main routes trade relations intra and extra Carpathian run through the Eastern Carpathians crossed by Oituz Gorge, and the Southern Carpathians by Bran Gorge. These passes are identified due to monetary discoveries.

In the intra-Carpathian area, one of the busiest roads was the one on the Mureş Valley, which was navigable up to Alba Iulia, connected in the west with Pannonia and that climbed up on Mureş until the confluence with Sebes. There, the road split in two branches: one following the course of the Mureş and Târnave rivers, and the other descended to the Olt River. In southern Transylvania, there are also signalled the road that connected the valley Cibinu-Tilişca and Căpâlna and the road, of great importance, on the Black River Valley, in the direction of the Moldavian territory of today. ${ }^{30}$ On this road, the drachmas of the cities Dyrrachium and Apollonia, as well as the Roman denarii entered Moldavia $^{31}$. Another road of entry in Moldavia for both the drachmas from Dyyrachium and Apollonia, and the Roman denarii could be the Siret and Prut through the Danube, where much of the Republican Romanian coin hoards from Poiana (Moldavia) closed in the second half of the $1^{\text {st }}$ century BC, after Pompey takes action against pirates. Most likely, the coins come in Moldova through the Greek cities from the Pontus-Euxinus coast. In the western part of Transylvania, Someş, Criş, Bega were also used as trade navigable routes, through which Roman and Greek coins might have entered in the area.

The roads mentioned above have not been designed especially for facilitating circulation before the Roman domination in Dacia. They are, however, sufficient, having acted as conduits for not only trade with the Greco-Roman world, but also for the internal exchange of commodities.

30 GLODARIU 1976, 117; MITREA 1958, 148

31 GLODARIU 1976, 117; MITREA 1958, 148. 

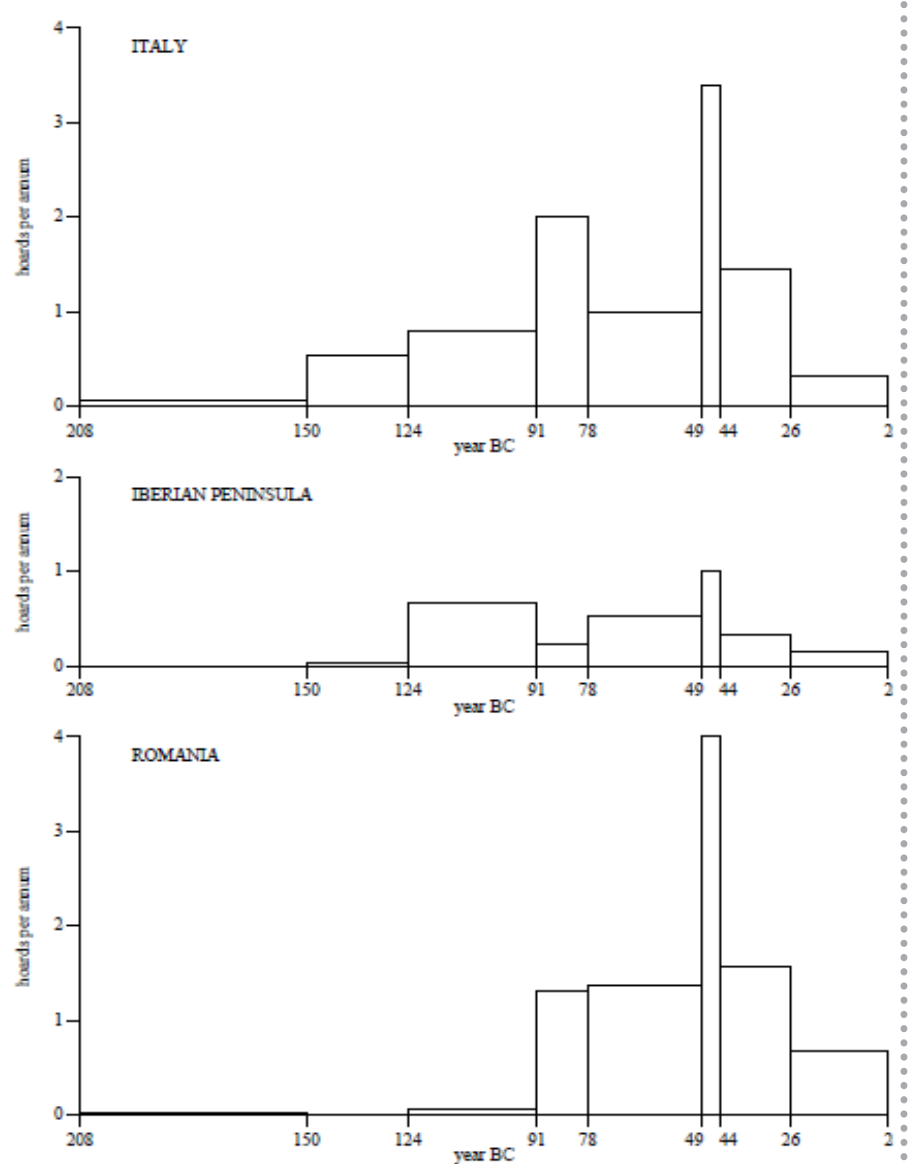

Figure 1. Denarius, hoards per annum from the Coin Hoards of the Roman republic (CHRR) database. ${ }^{32}$

The route is done mostly by combining navigable roads with land routes, as merchants preferred to transport goods by river and, when this was not possible, quickly switch to land transport. Since money supply was not regular, it is difficult to establish a pattern of supply. From the discovery of the trade routes, it is possible to establish which roads they entered in Dacian but not the period.

M. Crawford presents that the distribution of coin hoards in Italy during the Roman Republic period was not equal. He believed that coin hoards are closely correlated with significant historical events, and gives as an example the Social War between 90 and 88 BC years, he states that the volume of coins from that period is higher than during a normal period, in case of significant events monetary reservoirs larger than at other times. ${ }^{33}$ Other examples are given by Lockyear who comes and reinforces the idea with scientific proof. Analyzing the composition of a hoard from 147-50 BC, Lockyear shows that for a hoard of 100 coins, there is a 0.9995 probability that a hoard from $85 \mathrm{BC}$ will contain a coin of that year. Thus, according to this theory, a coin hoard that closes with a coin coming from a period consisting of a major historical event is less probable to be from the year the coin was mint. ${ }^{34}$ So, the pieces from a huge reservoir of circulating coins circulated for more time

32 LOCKYEAR 1996, 141

33 CRAWFORD 1969, 80.

34 LOCKYEAR 1993, 374-375. in the Republic, and it is most likely to meet them, closing hoards even after 10, 20, 30 years after minting. Other major historical events with impact on coin reservoirs are presented by K. Lockyear: The Social War (91-88 BC), the Spartacus uprising (73-71 BC) and most importantly the Civil War in the 40 s BC. ${ }^{35}$ Details regarding the coin reservoir in different chronological segments can be seen in figure. 1.

As seen in figure 1 , the social and civil wars increase the monetary basin in Italy and Romania, but not in the Iberian Peninsula. In the Iberian Peninsula the monetary basin grows only during the civil war just as in Romania and Italy, but the social war represented in figure 1 , between 91-78 BC does not cause an increase of the monetary basin compared to Italy and Romania.

The principle that connect the increase of the monetary pool to the importance of the historical events has served to K. Lockyear and M. Crawford in their attempts to approximate the time of the arrival of the Republican in Dacia.

In the following chapter are presented the theories that were rooted in the academic literature on the timing when the republican denarius arrived in Dacia.

\section{THE MOMENT DENARIUS ENTERS PRE-ROMAN}

\section{DACIA IN HISTORIOGRAPHY}

Due to their number, their frequency and the distribution area, the Roman Republican denarii were the main category of coins on the Geto-Dacian market since the $1^{\text {st }}$ century $\mathrm{BC}$, the circulation of Roman Republican denarii in Dacia implies chronological, economic and politica discussions. However, knowing when the coins were mint is not necessarily an advantage in dating the entry of the denarius in a given space. Some of the assumptions regarding the entry of the denarius in Dacia, based on welldocumented scientific arguments, will be discussed in this part of the study. Until the 1980s, C. Preda and Gh. PoenaruBordea consider it occurs sometimes between 80-70 BC; $\mathrm{M}$. Crawford talks about 65 BC; M. Babeş about the 50s BC and after. Later, Romanian traditional hypothesis placed this phenomenon somewhere in the $100 \mathrm{~s}$ BC. ${ }^{36}$ From a simple analysis of hoards, it is possible to notice that the $100 \mathrm{~s} \mathrm{BC}^{37}$ cannot be considered as the entering moment of Republican denarii in Dacia. The theories of M. Chițescu, ${ }^{38}$ M. Crawford, ${ }^{39}$ K. Lockyear, ${ }^{40}$ and other scholars will be presented in this part of the chapter.

The first to start with is M. Crawford, who, in his article „Republican Denarii in Romania the suppression of Piracy and the Slave trade", offers the results of precious analysis on the moment the denarii entered Dacia and not only. In the same paper, he offers some possible answers to the questions:

1. Why did the Romans exported so many denarii in this area?

2. What was the function of these coins in the Geto-

\footnotetext{
35 LOCKYEAR 1996, 140-144.

36 LOCKYEAR 1996, 387.

37 LOCKYEAR 1996, 388.

38 CHIT,ESCU 1981.

39 CRAWFORD 1977

40 LOCKEYEAR 1996; LOCKYEAR 2007.
} 


\section{Dacian society $?^{41}$}

First of all, M. Crawford wants to specify that this is rather a regional phenomenon, especially in the lower basin of Danube, in the second half of the first century BC and the modern Bulgaria is the only space that competes with the area of modern Romania in terms of findings of Roman Republican coins. ${ }^{42}$ Furthermore, he clearly points out that there is evidence that certify the need for precious metal in the lower basin of Danube in the Hellenistic period. He offers an inscription as a proof from Istria, which attest that the city can buy immunity and prevents invasion of 600 gold coins: „Agathocles son of Antiphilus, born of a father who was a benefactor, continues to be a good and honourable man towards the city and the citizens...and after this, when (the Thracians of the chieftain Zoltes) [invaded] the land, laid siege to Bizone and ravaged the land, and the harvest was imminent, he was elected ambassador and travelled to the (Thracian) army, and as the citizens had given him instructions to redeem the land and the crops at [all]/ cost, he persuaded Zoltes and the Thracians at a cost of 600 gold pieces [not to invade] the land nor to approach the city, which enabled [the] citizens to secure all the [crops] from the land." 43

Responding somewhat to the second question, Crawford said that, although there is a long history of silver coins in this space, most of the Greek cities, these coins have never had a strong commercial nature, of economic exchange, this happening also when the denarius entered, in the first century BC. The lack of any smaller denominations, to act as change in the economic life, in the market, make these coins not to work efficiently. ${ }^{44}$

Rather, he believes that these coins were used in the gift-exchange economy more than in a context of marketbased economy. ${ }^{45}$ As an analogy, he gives an example from Galia: „the father of King Bituitus of the Arverni displayed has wealth by scattering gold and silver coins from has chariot" 46

The hoards found show status, display wealth, together with jewels found in the same context. Actually, what Crawford argues is that populations of this area copy the Greco-Macedonian civilized world of the Mediterranean world. The author argues that it is not correct the idea according to which the ancient Geto-Dacian world changed when Greek coins were replaced with the Roman ones, since the social context remains the same, still there are no smaller denominations to take over the function of change in an economy based on the market and exchange. Moreover, comparing coin hoards from Romania and Italy, or from other parts of the Roman Republic, where the denarii circulated, notes the fact that most of hoards in Dacia are almost impossible to investigate chronologically since the coins of the hoard are chronologically separated by long periods, and between hoards, there are rather long time periods. What is different in the hoards studied in Italy, where the chronological difference between coins

41 CRAWFORD 1977, 118.

42 CRAWFORD 1977, 117.

43 AUSTIN 2006, 222.

44 CRAWFORD 1977, 118.

45 CRAWFORD 1977, 118

46 Strabo IV.2.3 are not noticeable and are consistent, having also smaller denominations used as change. Although the circulation of republican denarii is restricted in the basin of Lower Danube, M. Crawford considers that Dacia fails to reach a notable economic development in order to have a market economy. ${ }^{47}$

According to the same scholar, the dating of the moment when the denarii entered Dacia is problematic because most Republican denarii circulated for a long time, and theoretically, it is possible that all the coins have entered Dacia any time before the imperial period. However, he believes that $1^{\text {st }}$ century $\mathrm{BC}$ is the moment when denarii appear in pre-Roman Dacia, mainly at the end of the $1^{\text {st }}$ century BC, the first part, and then until the end of the Republic and after. This unique phenomenon can hardly be explained in terms of a constant trade activity, contradicting I. Glodariu. ${ }^{48}$ From an archaeological perspective, one can observe a wide variety of goods from the Mediterranean world on the territory of modern Romanian, even though their quantity cannot explain the large number of denarii in circulation on the territory of modern Romania.

M. Crawford contradicts most of the theories published at that time. Generally, those hypotheses claiming that the Republican denarii penetrated Dacia because of an intense trade relation with the Greco-Roman world. Mid-60s $\mathrm{BC}$ is the moment he considers the one of massive entry of Republican denarii in pre-Roman Dacia. Hoards that closed earlier than the 60s BC are considered as part of a broader reservoir of coins minted between the 90-70 BC, which arrived later in Dacia, due to rather large distance between Rome and pre-Roman Dacia. He provides an answer to the question that opened the analysis of his theory, namely: Why did the Romans exported so many denarii in this area? ${ }^{49}$ The explanation he offers is the intense slave trade, especially after the victorious campaign of Pompeius against pirates in $67 \mathrm{BC}$, merchants wanting to supply Rome, Italy but also the Mediterranean world with slave outside Greco-Roman world. Rome suffers severe losses of slaves also during the revolt of Spartacus. ${ }^{50}$

Pontus Euxinus is an area known and documented as being a good source of slaves. Slaves are mentioned by Polybius among the top five goods exported by populations around the Black Sea ${ }^{51}$. Crawford notices that after the pirates have bene stopped in the year $67 \mathrm{BC}$, trade in the Pontus space, mainly of slaves was monopolized by influential and rich people, from the West (Italian Peninsula), thus explaining the huge amounts of Republican denarii present in pre-Roman Dacia after the pirates had been defeated by Pompeius.

Using reports of antic authors - Strabo and Polybius - as well as interpreting historical events from the period, the author manages to converge towards his main theme, namely to observe the moment denarii entered pre-Roman Dacia.

Finally, the main point of Crafword's theory is that the presence of Roman Republican denarii in the geographical area of the Lower Danube basin is mainly caused by the 47 CRAWFORD 1977, 118.

48 GLODARIU 1976, 138.

49 CRAWFORD 1977, 119.

50 CRAWFORD 1977, 121.

51 Polybius IV, 38, 4 
the slave trade. This trade intensified after the pirates disappeared from the waters of the Mediterranean and Black Sea in $67 \mathrm{BC}$, along with other events occurring in the Italian peninsula that led to a demand for increasingly large slave market. Using the recordings of ancient authors: Strabo and Polybius, and the interpretation of historical events of the period, the author manages to converge towards his main theme, namely wants to observe the moment denarii entered pre-roman Dacia. ${ }^{52}$

Maria Chițescu offers another interesting hypothesis for the moment when Roman Republican denarii entered the geographical area of the Geto-Dacians. Chițescu claims that Republican denarii reached the Lower Danube basin as a result of payments by the Romans for mercenaries. ${ }^{53}$ Following the reseach on hoards, the author argues that, after analysing the first wave of coins arrived in Dacia, would have entered due to military needs from Rome, somewhere around $80 \mathrm{BC}$. She also claimed that the prevalence of $\mathrm{M}$. Antonius legionary coins in Dacia is explained only in terms of military assistance, which might represent a tradition. ${ }^{54}$ This argument is contradicted by Crawford, who say that it is true that Rome administration contracted barbarian mercenaries in case of military needs, but none of the information from that period certify any major military event. ${ }^{55}$ Moreover, the presence of the legionary currencies is not an argument according to Crawford because that kind of coin is widespread throughout coin hoards across the Mediterranean world long after $31 \mathrm{BC}$.

In dating the entry time of the Roman Republican denarius in the Dacian space, M. Chițescu considers that a careful analysis of the local replicas must be taken into account ${ }^{56}$, claiming that most of the coins of Roman type would be formed by coins minted by the locals, and the situation would be more difficult to explain. The lack of historical sources, both archaeological and literary on the exploitation of silver by Dacians. Another assumption in this case would be that old Greek coins were melted down. Over time, such coins have disappeared from circulation or have been used to mint copies of Roman Republican denarii. Thus, concluding the hypothesis offered by Chițescu, Roman Republican denarius reached the geographic area of the Dacians somewhere around $80 \mathrm{BC}^{57}$, using Sydenham's chronology.

The problem of imitations is interesting and intensely researched. Chițescu tried to identify how many denarius imitations are in Republican hoards found in Dacia. She also offers some criteria by which we can identify imitations, namely: coin weight, diameter, style, design or legend errors, errors in vivid jagged edge (serratus), the lack of cuts on coins, metallographic analysis. ${ }^{58}$

These criteria are analysed by K. Lockyear. ${ }^{59} \mathrm{He}$ believes that it is not enough to determine whether a coin is

\footnotetext{
52 CRAWFORD 1977, 119.

53 CHITESCU 1971, 159.

54 CHIŢESCU, 1981, 13.

55 GRIFFITH 1935, 234-5.

56 CHIȚESCU 1981, 10.

57 CHIT,ESCU 1981, 11-13.

58 CHIŢESCU 1977, 211.

59 LOCKYEAR 1996, 400.
}

counterfeited or not. ${ }^{60}$ The coin-dies found in Dacia at Tilișca and Ludeşti ${ }^{61}$ can strongly modify the patterns of supply. During antiquity, we have some well-known examples when currency is not minted by the state authority.

Over time, it got strongly naturalized the idea that only the state had the authority in ancient times to mint currency, being especially influenced by the Roman imperial period, when it was well-known that the state has the right to mint coins. There are some contexts where they know other ways. Individuals can beat themselves individually or initiate minting of coins that go with precious metal (ingot) to a mint ${ }^{62}$. Ch. Howgego gives us information about an inscription from the $3^{\text {rd }}$ century BC, which talks about a foreigner, named Polycharmos, who borrowed Olbia city with 100 gold pieces for the security of sacred vessels. When the city was unable to pay the debt, Polycharmos took their vessels to the mint and turned them into coins. ${ }^{63}$

In the same work, it is mentioned the Persian Didales who took silver in Amisos to be converted into coins for being able to pay his soldiers. It is to be seen whether these individual initiatives did not have somehow the approval of the local authorities, since these characters were in an institutional relation with them (Olbia and Amissos). These random sources offer too little information about this practice, if it was common in the ancient world or not ${ }^{64}$.

Chițescu presents a map of the distribution of coin hoards of the Roman Republican denarii in modern Romania at the level of 1981 (Map 2).

Using Crawford's identification method, Gh. PoenaruBordea and M. Cojocărescu unprecedented until that moment by Romanian authors, they manage to establish a pattern of coin hoarding of Roman republican denarius in pre-Roman Dacia. Thus, analysing the structure of the five hoards from Transylvania, they succeed in establishing a period of massive supply with the Roman Republican coin in Dacia somewhere between 75-65 BC, after which supply decreases strongly. ${ }^{65}$ Chițescu provides a possible explanation for this decrease. The third war with Mithradates, shortly followed by the founding of a new Dacian state around Burebista, claiming under this theory that, in these conditions GetoDacians started to imitate the Roman Republican coin. ${ }^{66}$

I. Glodariu speaking on the early Roman Republican coin entry in Dacia ${ }^{67}$ refers to C.Moisil who dated the entry of the Roman coin on the Dacian market at the end of $2^{\text {nd }}$ century BC. ${ }^{68} \mathrm{He}$ adjusted this chronology based on the one by E.A. Sydenham ${ }^{69}$ placing the dating around the year 100 BC. ${ }^{70}$ At the same time, I. Glodarius suggested that the denarius arrival in Dacia may have happened somewhere in

60 LOCKYEAR 1996, 406. Further details and analysis on issues regarding the imitations will not be discussed in this paper. This paper we will not discusse details and analysis regarding imitations, because the study employs and focus only on data that can offer chronological results.

61 LUPU 1967; CHIȚESCU 1980; 1981

62 HOWGEGO 1995, 33.

63 HOWGEGO 1995, 33.

64 HOWGEGO 1995, 34.

65 POENARU-BORDEA/COJOCĂRESCU 1984, 53-75.

66 CHIȚESCU 1971, 162-164.

67 GLODARIU 1976, 90.

68 MOISIL 1926, 83-85.

69 SYDENHAM 1952, 65.

70 GLODARIU 1976, 93. 


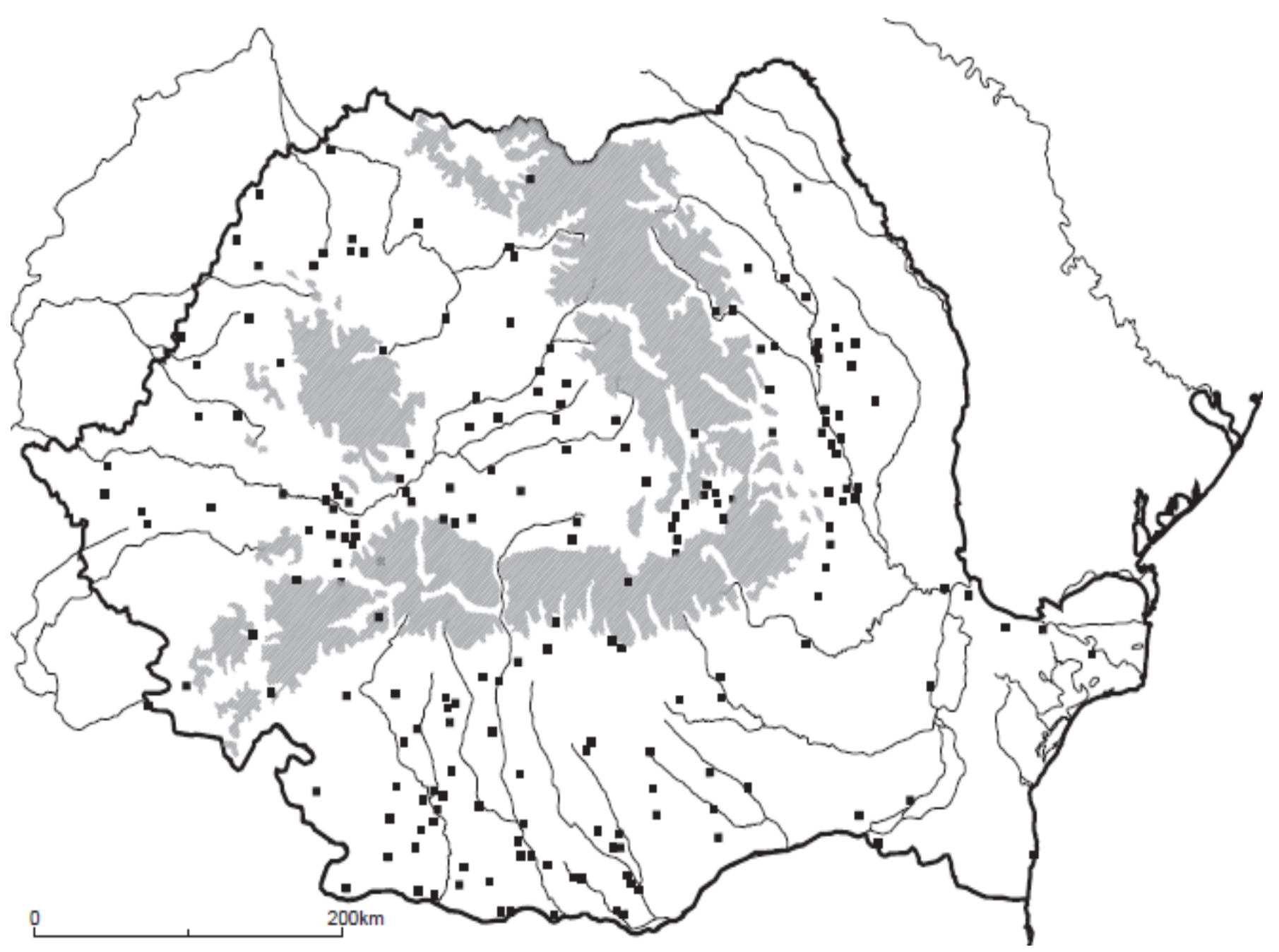

Map 2. Roman Republican Denarii distribution across Romania. ${ }^{71}$

the last century BC. ${ }^{72}$

Based on the oldest deposits, C. Preda argues that the early Roman Republican denarii began to enter in Dacia in 78-77 BC. ${ }^{73}$ C. Preda insists that it is not possible to discuss about a clear and precise statistics on the number of coins and hoards, as well as on their structure, because for most of the hoards, especially those discovered in the $19^{\text {th }}$ century and the first half of the 20th century, there are only vague or incomplete information. He also states that there are quite a few hoards of which only small parts have been preserved. ${ }^{74}$

Another hypothesis is theorized by M. Babeş. His theory is based on archaeological information, inspired from the excavations at Cârlomăneşti, where Inoteşti-Răcoasa type coins, a coin of Phillip III Arrhidaeus, a tetradrachma from Thasos and a drachma of Dyrrachium were found ${ }^{75}$ but no Republican coins. According to M. Babeş, the abundance of Roman Republican denarii in Dacia makes him conclude that this settlement archaeological was abandoned before the massive entry of denarii in Dacia. This conclusion creates the premises of an investigation on the moment the republican denarii arrived in Dacia.

\footnotetext{
71 LOCKYEAR 1996, 390.

72 GLODARIU 1976, 94

73 PREDA 1998, 291

74 PREDA 1998, 298.

75 BABEŞ 1975, 129-135.
}

M. Babeş presents a table that shows associations of mints between hoards found in Dacia (Tabel 1).

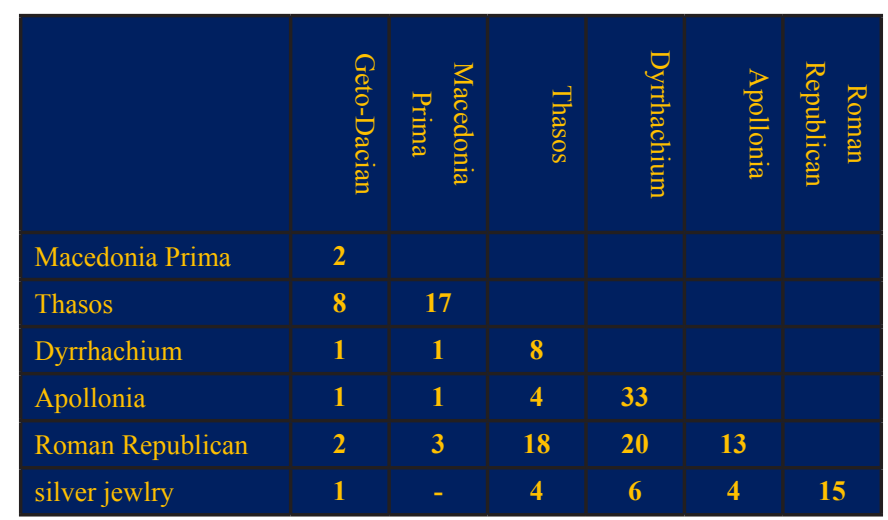

Table 1. Pair of coin hoards found in Dacia second century BC - first century. BC. ${ }^{76}$

This table clearly shows that the Romans denarii are rarely found with Geto-Dacian currencies, or currencies from Macedonia Prima, but often found together with coins from Thasos, Apollonia and Dyrrachium. The Illyran cities coins are usually found together, but not always, with Roman Republican denarii. M. Babeş considers that the vast

76 Based on BABEŞ 1975, 131, fig. 6; LOCKYEAR 1996, 387. 
majority of drachmas were issued probably between 125 $75 \mathrm{BC}$, and, because there are hoards of drachmas without denarii, he proposes two stages of coins' use:

- An 'old' phase with Geto-Dacian coins, tetradrachmas of Macedonia Prima and Thasos, and the first drachmas from Apollonia and Dyrrhachium;

- A 'recent' phase dated from the moment the Roman Republican denarii reaches Dacia and circulates together with drachmas from Apollonia, Dyrrachium and tetra drachmae from Thasos. ${ }^{77}$

This scholar considers that it may have taken some time from the moment the coins were minted in the Italian peninsula until they reached Dacia. He believes that it is unlikely that the denarius reached Dacia before $50 \mathrm{BC}{ }^{78}$ Thus, the 'old' phase ends in the 50s BC and then starts the 'recent' phase. Babeş provides an analysis different from those we were previously aware. His archaeological analysis may be correct. However, it is wrong to generalize without having similar situations from/at other archaeological sites. His analysis is different because it does not focus on each coin as other authors do (M. Crawford, M. Chițescu, K. Lockyear). The results of his analyses are mainly based on archaeological research.

The last hypothesis on the entry of Roman Republican denarii in Dacia presented in this paper is that of $\mathrm{K}$. Lockyear. ${ }^{79}$ This scholar makes a thorough analysis of 217 Roman Republican hoards of the ancient world. ${ }^{80}$ He noticed a strong similarity between hoards dating from the period 75$65 \mathrm{BC}$ in Italy and Romania using the Crawford chronology from 1974. This makes Lockyear to claim that it is very unlikely that the first major stream of Republican denarii occurred during this period. Although there are similarities between his theory and that of Crawford, the entry moment of denarii is slightly different, with a difference of $15-10$ years. Crawford claims that it could have happened in that period because the denarius had to cover large distances until reaching Dacia. ${ }^{81}$ On the other hand, Lockyear states that, considering the lack of Republican coins in the regions between the Italic Peninsula and Dacia, it is very likely that the denarius reached Dacia from commercial reasons, being directly transported from Italy to Dacia. ${ }^{82}$ Just as Crawford, he claims that slaves' trade is more likely to be the main trade 'material' between Geto-Dacians and Romans. ${ }^{83}$ According to K. Lockyear, it is very unlikely that the denarii reached Dacia before $90 \mathrm{BC}$, thus contradicting the type of supply suggested by D. Moisil and G. Depeyrot ${ }^{84}$ that, after K. Lockyear, cannot be supported by evidence obtained from coin hoards. ${ }^{85}$

\section{ENTRY DATE FOR THE ROMAN REPUBLICAN}

\section{DENARIUS IN DACIA}

In developing a new hypothesis regarding the entry of

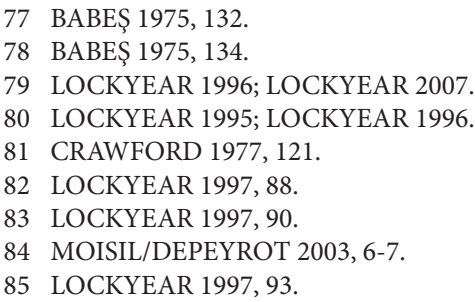

the Roman Republican denarius in Dacia, several technical precautions were taken into account.

The databases for Roman Republican hoards used in this current paper are based on work by D. Moisil and G. Depeyrot, ${ }^{86}$ and K. Lockyear. ${ }^{87}$ Based on the information taken from these databases, a table was created (Table 2) that will serve as our database to generate statistic information.

The hypothesis presented in this study on the entry date for the Roman Republican denarius in Dacia will be based strictly on the table and on the Map 3.1 from which have been taken several time segments to observe different geographic distribution of hoards by different chronological segments. Time segments will be 10 years. This interval was chosen for the present research for methodological reasons. It shows how quickly a coin is removed from the coinage pool $^{88}$. Because the supply area was erratic at best ${ }^{89}$, keeping the decade intervals gives a short enough span to capture significant changes in suplly and distribution. It must be mention here that all the hoards were mapped on the ROTEZ platform created by C. Găzdac: http://tezauremonetare.ro/.

\section{SETTING UP THE DATA BASIS AND STATISTICAL}

\section{GRAPHICS}

The study is based on Table 2 that was creating following K. Lockyear's model ${ }^{90}$, which includes all the hoards with Roman Republican denarii discovered on the territory of Romania. $\begin{array}{ll}86 & \text { MOISIL/DEPEYROT } 2003 . \\ 87 & \text { LOCKYEAR } 1996 . \\ 88 & \text { LOCKYEAR 1996, } 110 . \\ 89 & \text { LOCKYEAR 1996, } 257 . \\ 90 & \text { LOCKYEAR 1996, 394-396. }\end{array}$ 


\begin{tabular}{|c|c|c|c|c|c|c|c|c|c|c|c|}
\hline HOARDS & 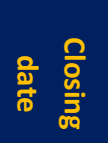 & $\begin{array}{c}\text { Dr. } \\
\text { Apollo- } \\
\text { nia }\end{array}$ & $\begin{array}{l}\text { Dr. Dyr- } \\
\text { rachium }\end{array}$ & $\begin{array}{c}\text { Tdr. } \\
\text { Macedo- } \\
\text { nia Prima }\end{array}$ & $\begin{array}{c}\text { Tdr. } \\
\text { Thasos }\end{array}$ & Denarius & $\begin{array}{c}\text { Copies } \\
\text { Dr. Apol- } \\
\text { Ionia }\end{array}$ & $\begin{array}{l}\text { Copies } \\
\text { Dr. Dyr- } \\
\text { rachium }\end{array}$ & $\begin{array}{l}\text { Copies } \\
\text { Tdr. Tha- } \\
\text { sos }\end{array}$ & $\begin{array}{l}\text { Copies } \\
\text { Denarius }\end{array}$ & TOTAL \\
\hline Târgu Mureş & 90 & & & & & 3 & & & & & 3 \\
\hline Hilib & 89 & & 76 & & 22 & 1 & & 3 & & & 101 \\
\hline Priseaca & 88 & & & & & 2 & & & & & 2 \\
\hline cremenari & 87 & & & & & 2 & & & & & 2 \\
\hline Drăgeşti & 85 & 121 & 9 & & & 3 & & 3 & & & 136 \\
\hline $\begin{array}{l}\text { Valea Voievo- } \\
\text { zilor }\end{array}$ & 85 & & & & & 8 & & & & & 8 \\
\hline Floreşti & 84 & & & & & 2 & & & & & 2 \\
\hline Iclanzel & 84 & & & & & 18 & & & 2 & & 20 \\
\hline $\begin{array}{l}\text { Amărăştii de } \\
\text { Jos }\end{array}$ & 84 & & & & & 4 & & & & & 4 \\
\hline Zimnicea & 83 & & 11 & & & 10 & & & & & 21 \\
\hline Luduş & 82 & & & & & 2 & & & & & 2 \\
\hline Medveș & 82 & & & & & 13 & & & & & 13 \\
\hline Varmaga & 81 & & & 1 & 3 & 1 & & & & & 5 \\
\hline Nedeia & 79 & & & & & 19 & & & & & 19 \\
\hline Moisei & 79 & & & & & 5 & & & & & 5 \\
\hline Suhaia I & 79 & & 10 & & & 25 & & & 3 & & 38 \\
\hline Sălaşuri & 79 & & & & & 4 & & & & & 4 \\
\hline Nuşfalău & 79 & & & & & 17 & & & & & 17 \\
\hline Moroda II & 79 & 1 & & & & 11 & & & & & 12 \\
\hline Gliganul de Jos & 79 & & & & & 11 & & & & & 11 \\
\hline Albeşti & 79 & & & & & 10 & & & & & 10 \\
\hline Bălăneşti & 78 & & & & & 10 & & & & & 10 \\
\hline Bobaia & 77 & 29 & 139 & & 16 & 40 & & 17 & 9 & 1 & 251 \\
\hline Inuri & 77 & & & & & 37 & & & & & 37 \\
\hline Mierea & 77 & & & & & 3 & & & & & 3 \\
\hline Fundeni & 77 & & 1 & & & 1 & & & & 1 & 3 \\
\hline Somosches & 76 & 73 & & & & 10 & & & & & 83 \\
\hline Cornetu & 75 & & 1 & & & 127 & & & & 1 & 129 \\
\hline Zătreni & 75 & & & & & 41 & & & & & 41 \\
\hline Mihai Bravu & 75 & & & & & 56 & & & & 1 & 57 \\
\hline Poroschia & 75 & & & & 39 & 85 & & & & & 124 \\
\hline $\begin{array}{l}\text { Stejeriş } \\
\text { (Braşov) }\end{array}$ & 75 & & 1 & & 6 & 200 & & & & & 207 \\
\hline Hunedoara II & 75 & & 35 & & & 42 & & & & & 77 \\
\hline Jdioara & 74 & & & & & 69 & & & & & 69 \\
\hline Năsăud & 74 & & & & & 8 & & & & & 8 \\
\hline Mihaiesti & 74 & & & & & 14 & & & & & 14 \\
\hline Lunca & 74 & & & & & 10 & & & & 2 & 12 \\
\hline Segarcea & 74 & & & & & 8 & & & & & 8 \\
\hline Ticleni (Tunşi) & 73 & & 1 & & & 132 & & & & & 133 \\
\hline
\end{tabular}




\begin{tabular}{|c|c|c|c|c|c|c|c|c|c|c|c|}
\hline HOARDS & 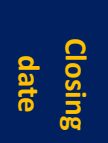 & $\begin{array}{c}\text { Dr. } \\
\text { Apollo- } \\
\text { nia }\end{array}$ & $\begin{array}{l}\text { Dr. Dyr- } \\
\text { rachium }\end{array}$ & $\begin{array}{c}\text { Tdr. } \\
\text { Macedo- } \\
\text { nia Prima }\end{array}$ & $\begin{array}{c}\text { Tdr. } \\
\text { Thasos }\end{array}$ & Denarius & $\begin{array}{c}\text { Copies } \\
\text { Dr. Apol- } \\
\text { Ionia }\end{array}$ & $\begin{array}{l}\text { Copies } \\
\text { Dr. Dyr- } \\
\text { rachium }\end{array}$ & $\begin{array}{l}\text { Copies } \\
\text { Tdr. Tha- } \\
\text { sos }\end{array}$ & $\begin{array}{c}\text { Copies } \\
\text { Denarius }\end{array}$ & TOTAL \\
\hline Talpe & 71 & 61 & & & & 21 & 4 & & & & 86 \\
\hline Sfinţeşti & 71 & & & & 13 & 92 & & & & 1 & 106 \\
\hline Hotaroaia & 71 & & & & & 9 & & & & & 9 \\
\hline Bancu & 71 & & & & & 3 & & & & & 3 \\
\hline Mărtiniş & 70 & & & & 1 & 15 & & & & & 16 \\
\hline Tincova & 69 & & & & & 155 & & & & 1 & 156 \\
\hline Viişoara & 69 & & & & & 2 & & & & & 2 \\
\hline Zimnicea II & 67 & & & & & 3 & & & & & 3 \\
\hline Grădiştea & 67 & & & & 1 & 21 & & & & & 22 \\
\hline Cernat & 65 & & 1 & & & 4 & & & & & 5 \\
\hline Curtea de & 64 & & & & & 10 & & & & & 10 \\
\hline \multicolumn{12}{|l|}{ Argeş } \\
\hline Peteni & 64 & & & & & 36 & & & & 3 & 39 \\
\hline Mofleni & 64 & & & & & 6 & & & & & 6 \\
\hline Craiova & 64 & & & & & 14 & & & & & 14 \\
\hline Oltina & 64 & & & & & 8 & & & & & 8 \\
\hline Socol & 63 & 3 & 10 & & & 38 & & & & & 51 \\
\hline Arcuş & 63 & & 208 & & 3 & 47 & & 1 & & & 259 \\
\hline Licuriciu & 63 & & & & & 63 & & & & & 63 \\
\hline Garvan & 63 & & & & & 29 & & & & & 29 \\
\hline Bazias & 63 & 3 & 10 & & & 38 & & & & & 51 \\
\hline Secusigiu & 62 & & & & & 23 & & & & & 23 \\
\hline Bonteşti & 62 & & & & & 36 & & & & 1 & 37 \\
\hline Sopot & 62 & & & & & 29 & & & & 3 & 32 \\
\hline Alungeni & 59 & & & & & 33 & & & & 1 & 34 \\
\hline Axente Sever & 56 & & & & & 563 & & & & & 563 \\
\hline \multicolumn{12}{|l|}{ (Frauendorf) } \\
\hline Someșul Cald & 56 & & 318 & & & 117 & & & & & 435 \\
\hline Amnas & 56 & & & & & 157 & & & & 2 & 159 \\
\hline Icland & 56 & & & & 2 & 33 & & & & 1 & 36 \\
\hline Dunăreni & 56 & & & & & 128 & & & & & 128 \\
\hline Satu Nou & 56 & & & & & 125 & & & 1 & 4 & 130 \\
\hline Chiţorani & 54 & & 2 & & & 9 & & & & 1 & 12 \\
\hline Buzău & 54 & & & & 1 & 45 & & & & & 46 \\
\hline Călineşti & 54 & & & & 3 & 92 & & & & 6 & 101 \\
\hline Sălaşu de Sus & 54 & & & & & 97 & & & & 14 & 111 \\
\hline Stăncuţa & 52 & & & & 53 & 34 & & & & & 87 \\
\hline Roata de Jos & 49 & & & & & 35 & & & & & 35 \\
\hline Brancoveanu & 48 & & & & & 12 & & & & 1 & 13 \\
\hline Afumaţi & 48 & & & & & 6 & & & 1 & & 7 \\
\hline Ploieşti I & 48 & & & & & 6 & & & & & 6 \\
\hline Târnava I & 48 & & & & & 25 & & & & & 25 \\
\hline
\end{tabular}

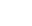




\begin{tabular}{|c|c|c|c|c|c|c|c|c|c|c|c|}
\hline HOARDS & 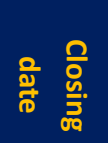 & $\begin{array}{c}\text { Dr. } \\
\text { Apollo- } \\
\text { nia }\end{array}$ & $\begin{array}{l}\text { Dr. Dyr- } \\
\text { rachium }\end{array}$ & $\begin{array}{c}\text { Tdr. } \\
\text { Macedo- } \\
\text { nia Prima }\end{array}$ & $\begin{array}{c}\text { Tdr. } \\
\text { Thasos }\end{array}$ & Denarius & $\begin{array}{c}\text { Copies } \\
\text { Dr. Apol- } \\
\text { lonia }\end{array}$ & $\begin{array}{l}\text { Copies } \\
\text { Dr. Dyr- } \\
\text { rachium }\end{array}$ & $\begin{array}{l}\text { Copies } \\
\text { Tdr. Tha- } \\
\text { sos }\end{array}$ & $\begin{array}{c}\text { Copies } \\
\text { Denarius }\end{array}$ & TOTAL \\
\hline $\begin{array}{l}\text { Orbeasca de } \\
\text { Sus }\end{array}$ & 48 & & & & & 140 & & & & 3 & 143 \\
\hline Căpruța & 48 & & & & & 16 & & & & & 16 \\
\hline Cuceu & 47 & & & & 35 & 486 & & & & 2 & 523 \\
\hline Locusteni & 47 & & & & & 88 & & & & 1 & 89 \\
\hline Bârsa & 47 & & & & & 28 & & & & 1 & 29 \\
\hline Ilieni & 47 & & & & & 111 & & & & & 111 \\
\hline Sprâncenata I & 46 & & & & & 110 & & & & & 110 \\
\hline Târnava II & 46 & & & & & 148 & & & & & 148 \\
\hline Comosteni & 46 & & & & & 2 & & & & & 2 \\
\hline Găiceana & 46 & & & & & 5 & & & & & 5 \\
\hline Goranu & 46 & & & & & 5 & & & & & 5 \\
\hline Hârlău & 46 & & & & & 3 & & & & & 3 \\
\hline Râmnicu Vâlcea & 46 & & & & & 43 & & & & & 43 \\
\hline Galesti & 46 & & & & & 43 & & & & 1 & 44 \\
\hline Vasad & 46 & & 1 & & & 67 & & & & & 68 \\
\hline Bord & 44 & & & & & 200 & & & & & 200 \\
\hline Cerbal & 43 & & & & & 447 & & & & & 447 \\
\hline Jegălia & 43 & & & & & 450 & & & 2 & 40 & 492 \\
\hline $\begin{array}{l}\text { Piatra Roşie } \\
\text { (Luncani) }\end{array}$ & 43 & & & & & 268 & & & & 9 & 277 \\
\hline Suhaia II & 42 & & & & & 10 & & & & & 10 \\
\hline $\begin{array}{l}\text { Nicolae Bălces- } \\
\text { cu I }\end{array}$ & 42 & & & 1 & & 31 & & & & & 32 \\
\hline $\begin{array}{l}\text { Nicolae Bălces- } \\
\text { cu II }\end{array}$ & 42 & & & & & 43 & & & & 2 & 45 \\
\hline Ploieşti II & 42 & & & & & 5 & & & & & 5 \\
\hline Bran & 42 & & & & & 63 & & & & & 63 \\
\hline Cădea & 42 & & & & & 131 & & & & 22 & 153 \\
\hline Fărcaşele I & 42 & & & & & 81 & & & & 3 & 84 \\
\hline Fărcaşele II & 42 & & & & & 113 & & & & 7 & 120 \\
\hline Fântânele & 42 & & 1 & & 1 & 8 & & & & & 10 \\
\hline Mangalia & 42 & & & & & 13 & & & & & 13 \\
\hline Murighiol & 42 & & & & & 8 & & & & 1 & 9 \\
\hline Ocniţa & 42 & & & & & 16 & & & & & 16 \\
\hline Vlădeni & 42 & & & & & 13 & & & & 1 & 14 \\
\hline Apoldu I de Sus & 41 & & & & & 498 & & & & 2 & 500 \\
\hline Işalniţa & 41 & & & & & 133 & & & & 1 & 134 \\
\hline Puieşti & 41 & & & & & 27 & & & & 1 & 28 \\
\hline Sadova & 41 & & & & & 35 & & & & & 35 \\
\hline Stupini & 41 & & & & & 229 & & & & 2 & 231 \\
\hline Lipovu & 40 & & & & & 7 & & & & & 7 \\
\hline Poroschia II & 39 & & & & & 533 & & & & 19 & 552 \\
\hline
\end{tabular}




\begin{tabular}{|c|c|c|c|c|c|c|c|c|c|c|c|}
\hline HOARDS & 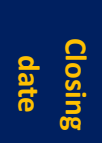 & $\begin{array}{c}\text { Dr. } \\
\text { Apollo- } \\
\text { nia }\end{array}$ & $\begin{array}{l}\text { Dr. Dyr- } \\
\text { rachium }\end{array}$ & $\begin{array}{c}\text { Tdr. } \\
\text { Macedo- } \\
\text { nia Prima }\end{array}$ & $\begin{array}{c}\text { Tdr. } \\
\text { Thasos }\end{array}$ & Denarius & $\begin{array}{c}\text { Copies } \\
\text { Dr. Apol- } \\
\text { Ionia }\end{array}$ & $\begin{array}{l}\text { Copies } \\
\text { Dr. Dyr- } \\
\text { rachium }\end{array}$ & $\begin{array}{l}\text { Copies } \\
\text { Tdr. Tha- } \\
\text { sos }\end{array}$ & $\begin{array}{c}\text { Copies } \\
\text { Denarius }\end{array}$ & TOTAL \\
\hline Tulcea & 38 & & & & & 14 & & & & 3 & 17 \\
\hline Vişină & 38 & & & & & 140 & & & & 6 & 146 \\
\hline Mordora I & 38 & & & & & 10 & & & & & 10 \\
\hline Racatau II & 37 & & & & & 53 & & & & 2 & 55 \\
\hline Beclean & 33 & & & & & 26 & & & & 5 & 31 \\
\hline Biled & 31 & & & & & 4 & & & & & 4 \\
\hline Breasta & 31 & & & & & 9 & & & & 2 & 11 \\
\hline Costineşti & 31 & & & & & 17 & & & & & 17 \\
\hline Deva & 31 & 42 & 101 & & & 2 & & 1 & & & 146 \\
\hline Grozăveşti & 31 & & & & & 51 & & & & 2 & 53 \\
\hline Gura Padinii & 31 & & & & & 232 & & & 2 & & 235 \\
\hline Roşiori de Vede & 31 & & & & & 6 & & & & & 6 \\
\hline Pietroasele & 31 & & & & & 2 & & & & 1 & 3 \\
\hline Prejmer & 31 & & & & & 153 & & & & 8 & 161 \\
\hline Târgu Ocna & 31 & & & & & 14 & & & & 1 & 15 \\
\hline Vladiceni & 31 & & & & & 3 & & & & & 3 \\
\hline Mărgineni & 30 & & & & & 18 & & & & & 18 \\
\hline Drăgeşti II & 29 & & & & & 5 & & & & & 5 \\
\hline Şeica Mică & 27 & & & & & 348 & & & & & 348 \\
\hline Poiana IV & 23 & & & & & 34 & & & & & 34 \\
\hline Dăeşti II & 19 & & & & & 4 & & & & & 4 \\
\hline Plopşor & 19 & & & & & 52 & & & & & 52 \\
\hline Valea & 19 & & & & & 212 & & & & 3 & 215 \\
\hline Cornii de Sus & 18 & & & & & 112 & & & & 1 & 113 \\
\hline $\begin{array}{l}\text { Simleul Sil- } \\
\text { vaniei II }\end{array}$ & 18 & & & & & 54 & & & & & 54 \\
\hline $\begin{array}{l}\text { Bordeştii de } \\
\text { Sus }\end{array}$ & 16 & & & & & 44 & & & & & 44 \\
\hline Scurtă & 16 & & & & & 12 & & & & 2 & 14 \\
\hline Voineşti & 16 & & & & & 93 & & & & 1 & 94 \\
\hline Cetăţeni & 13 & & & & & 122 & & & & 5 & 127 \\
\hline Pârgăreşti & 13 & & & & & 6 & & & & & 6 \\
\hline Poiana I & 13 & & & & & 143 & & & & 9 & 152 \\
\hline $\begin{array}{l}\text { Sfântu Gheo- } \\
\text { rghe }\end{array}$ & 13 & & & & & 61 & & & & & 61 \\
\hline Ciupercenii Noi & 12 & & & & & 161 & & & & & 161 \\
\hline Conteşti & 12 & & & & & 141 & & & & 6 & 147 \\
\hline Hunedoara V & 12 & & & & & 16 & & & & & 16 \\
\hline Spring & 12 & & & & & 50 & & & & & 50 \\
\hline Poiana V & 10 & & & & & 194 & & & & & 194 \\
\hline Remetea & 9 & & & & & 61 & & & 7 & & 68 \\
\hline \multicolumn{12}{|l|}{ Mare } \\
\hline Răcătău I & 8 & & & & & 68 & & & & 3 & 71 \\
\hline
\end{tabular}
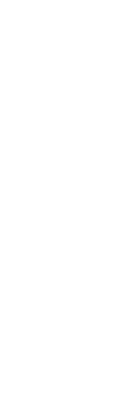


\begin{tabular}{|c|c|c|c|c|c|c|c|c|c|c|c|}
\hline HOARDS & 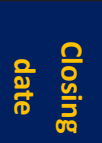 & $\begin{array}{c}\text { Dr. } \\
\text { Apollo- } \\
\text { nia }\end{array}$ & $\begin{array}{l}\text { Dr. Dyr- } \\
\text { rachium }\end{array}$ & $\begin{array}{c}\text { Tdr. } \\
\text { Macedo- } \\
\text { nia Prima }\end{array}$ & $\begin{array}{c}\text { Tdr. } \\
\text { Thasos }\end{array}$ & Denarius & $\begin{array}{c}\text { Copies } \\
\text { Dr. Apol- } \\
\text { Ionia }\end{array}$ & $\begin{array}{l}\text { Copies } \\
\text { Dr. Dyr- } \\
\text { rachium }\end{array}$ & $\begin{array}{l}\text { Copies } \\
\text { Tdr. Tha- } \\
\text { sos }\end{array}$ & $\begin{array}{c}\text { Copies } \\
\text { Denarius }\end{array}$ & TOTAL \\
\hline Breaza & 7 & & & & & 122 & & & & & 122 \\
\hline Bărboşi & 4 & & & & & 354 & & & & 14 & 368 \\
\hline $\begin{array}{l}\text { Șimleu Silvaniei } \\
\text { । }\end{array}$ & 4 & & & & & 36 & & & & & 36 \\
\hline Fitioneşti II & 4 & & & & & 74 & & & & & 74 \\
\hline Viile & 4 & & & & & 51 & & & & & 51 \\
\hline TOTAL & & 333 & 936 & 2 & 199 & 11324 & 4 & 25 & 27 & 237 & 13087 \\
\hline
\end{tabular}

In this table are presented coin hoards in a decreasing chronological order for the interval $90 \mathrm{BC}-\mathrm{AD} 4$ according to the closing year of each hoard. Thus, each hoard is displays information on the closing date, the exact number of coins found in the hoard plus number of imitations by coin type. Such a table can be obviously useful in projecting statistic graphics.

The program used for creating each graphic as well as of the table was Microsoft Excel.

Thus, based on the Table 2, there were elaborated several statistic projections relevant in dating the moment of entry of the Roman Republican denarii in Dacia. Any information resulted from a graph and statistic exercise must pass through various objective filters, or compared

with other hypothesis that does not necessarily result from statistic projections. Also using the Table 2 are all the hoards were mapped where they were found, as it can be seen in Map 3.

Dividing the temporal segment $90 / 11$ BC by decades, it is possible to observe a few coin hoards with Roman Republican denarii (denarii only), but also together with other coin types appear in different decades from the temporal segment discussed (Figure 2).

In this graph, the horizontal axis shows the decades (conventional temporal segments) while the vertical axis presents the number of coin hoards. According to this graph, there are three moments of growth for the coin hoards that contain Roman Republican denarii: 80/71 BC; 60/51 BC;

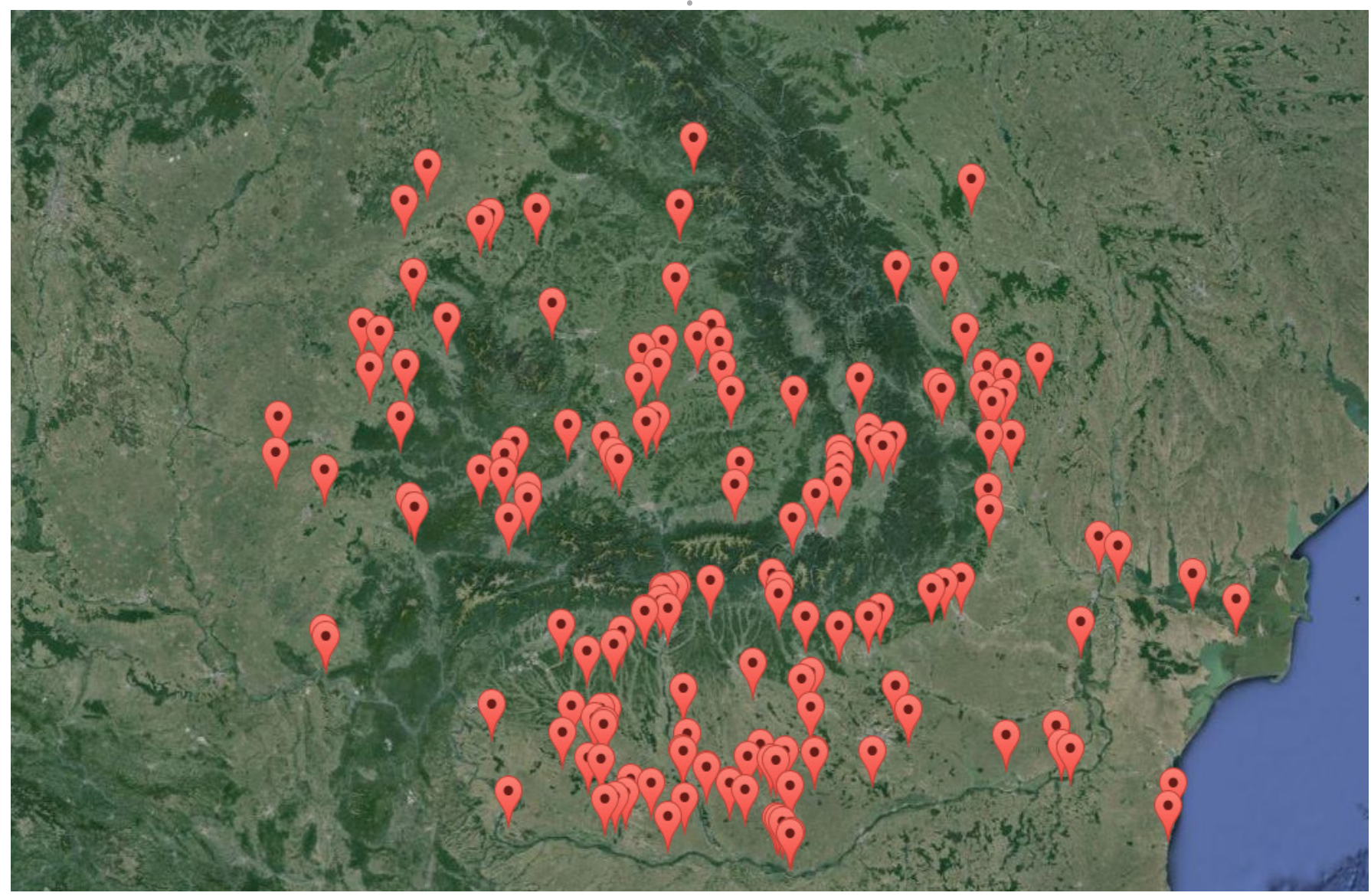

Map 3. The 166 coinh hoards consisting of Roman republican denarii.9

91 http://tezauremonetare.ro/maps?utf8=\%E2\%9C\%93\&q\%5Blocation cont $\% 5 \mathrm{D}=\& \mathrm{q} \% 5 \mathrm{~B}$ period cont $\% 5 \mathrm{D}=$ republican $\& \mathrm{q} \% 5 \mathrm{~B}$ province cont $\% 5 \mathrm{D}=\& \mathrm{q} \% 5 \mathrm{Broad}$ true $\% 5 \mathrm{D}=0 \& \mathrm{q} \% 5 \mathrm{Broad}$ false $\% 5 \mathrm{D}=0 \&$ commit=Search 


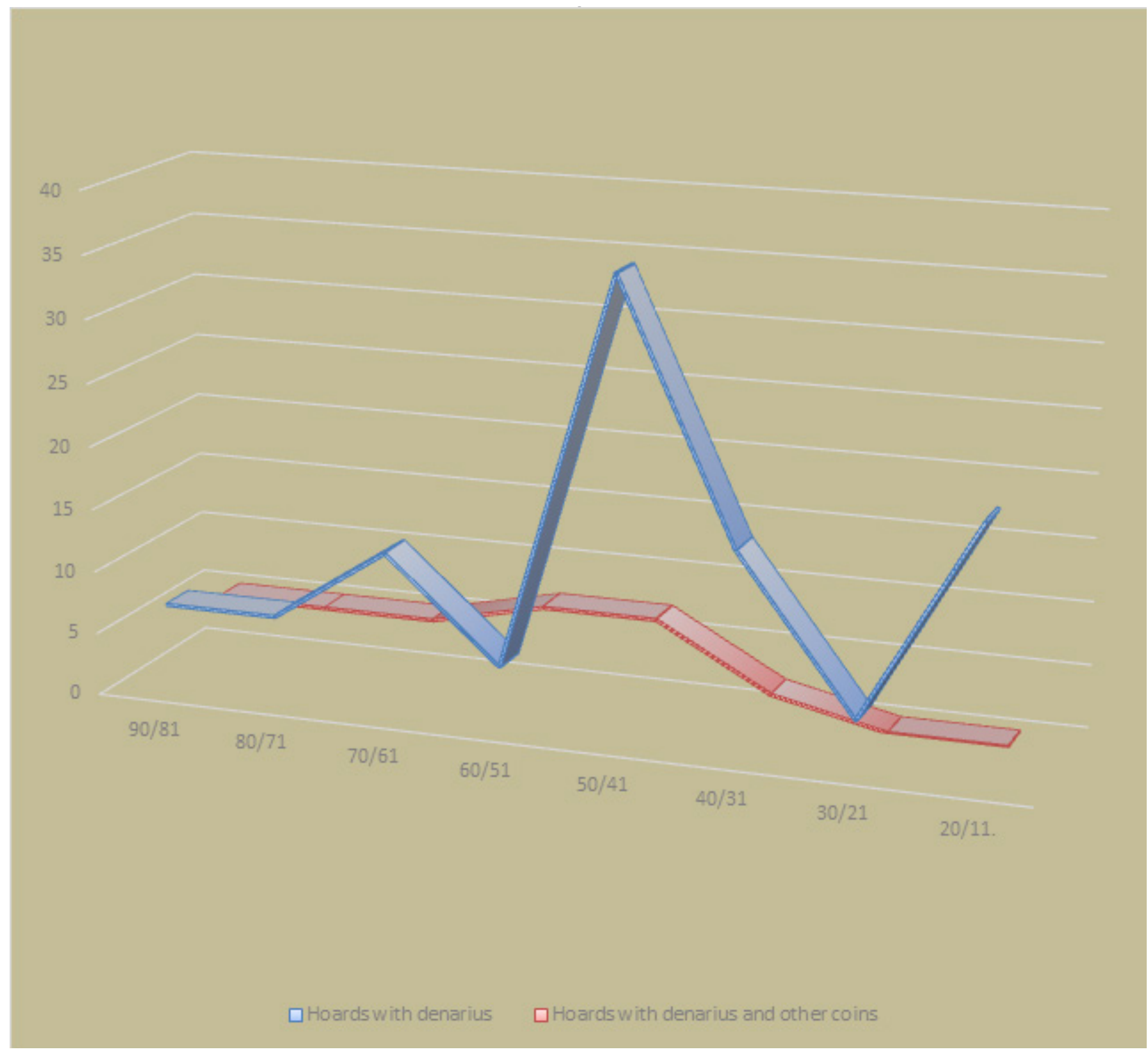

Figure 2. Roman coin hoards of Republican denarii and other currencies projected by decades on different temporal segment $90 / 11$ BC.

30/21 BC.

This graphic shows the interest for silver coins among Geto-Dacians and the preference for denarius against other currencies.

\section{STATISTIC ANALYSIS}

The focus will be on the analysis of specific temporal segments. Temporal segments when the number of hoards grows will be carefully observed.

A constant growth of coin hoards containing denarii can be observed for the moment 80/71 BC (Corneţu, Zatreni, Poroschia). A stagnation of mix hoards sometimes can be noticed in the middle of the interval 70 and $61 \mathrm{BC}$ when coin hoards containing exclusively Roman Republican denarii are fewer, the mix coin hoards grow a little bit and so do the number of Greek cities (see Figure 3).

\section{MONETARY HOARDS FROM 75/61 BC}

In Figure 3, the horizontal axis represents the names of the cities where the hoards were found and the vertical axis the number of each type of coins found in the hoards. Thus, starting with 69 BC (Tincova and Viişoara) the number of Roman Republican denarii from hoards decrease and the number of coins from Greek cities slightly increases (especially of drachmas from Dyrrachium, see Socol, Arcuş and Baziaş).

Between 60 and $51 \mathrm{BC}$ it is recorded the lowest level of hoards containing the Republican denarii. A constant increase starts and reaches the highest level between 50 and $41 \mathrm{BC}$, while the number of mix hoards stagnates, so that between 50 and $41 \mathrm{BC}$ it decreases until completely disappearing. This aspect was also noticed by M. Babeş. ${ }^{92}$

Another interesting fact can be noticed between 59 and $52 \mathrm{BC}$ when the number of hoards reached a minimum level, the number of coins from the hoards increases significantly as presented in Graphic 4.

92 BABEŞ 1975, 131. 


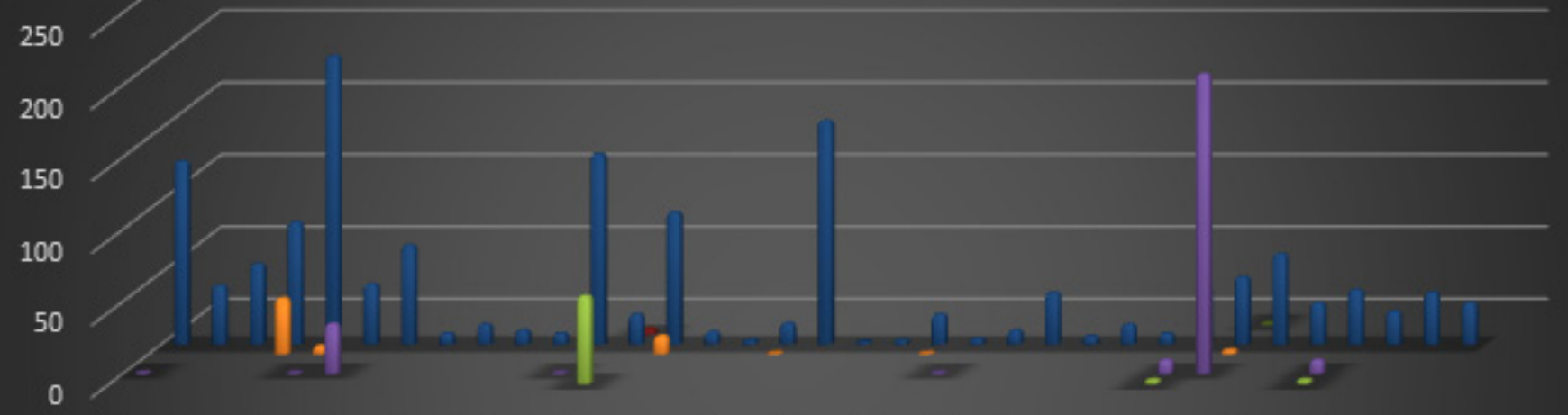

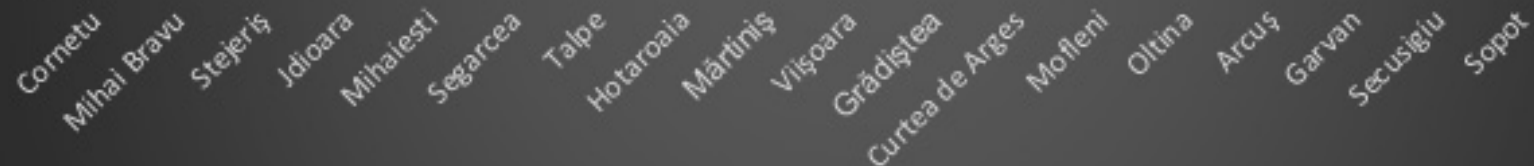

$\begin{array}{lll}\text { * Dr. Apollonia } & * \text { Dr. Dyrrachium } & * \text { Tdr. Macedonia Prima } \\ \text { * Tdr. Thasos } & * \text { Denar } & * \text { Copies of Dr. Apollonia } \\ \text { * Copies of Dr. Dyrrachium } & \text { C Copies of Tdr. Thasos } & * \text { Copies of Dena }\end{array}$

Figure 3. Monetary hoards with Roman Republican denarii and mix coin hoards from the years 75/61 BC according to the Table 2.

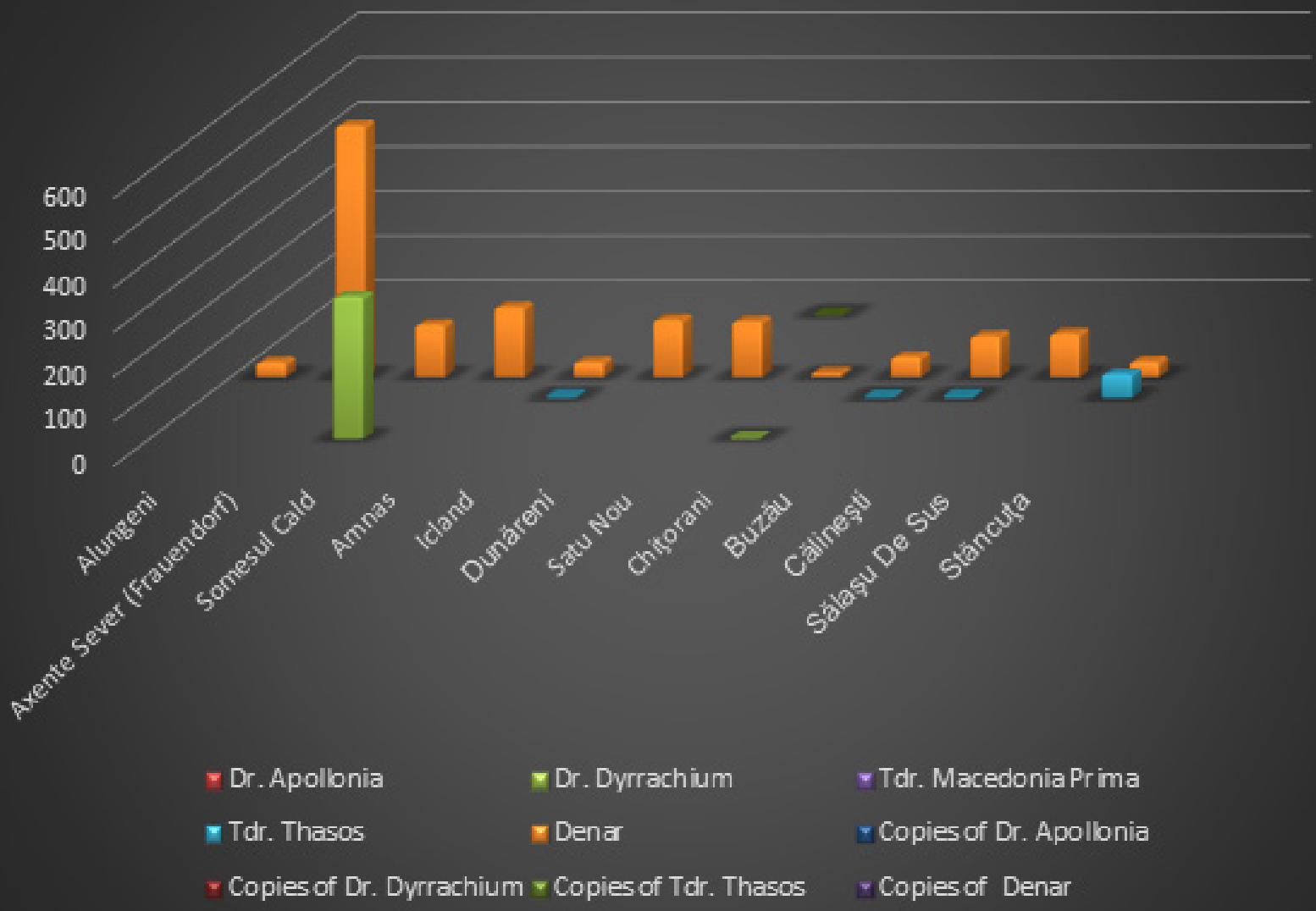

Figure 4. Monetary hoards with Roman Republican denarii and mix coin hoardss from the years 59/52 BC according to the Table 2. 
Studies

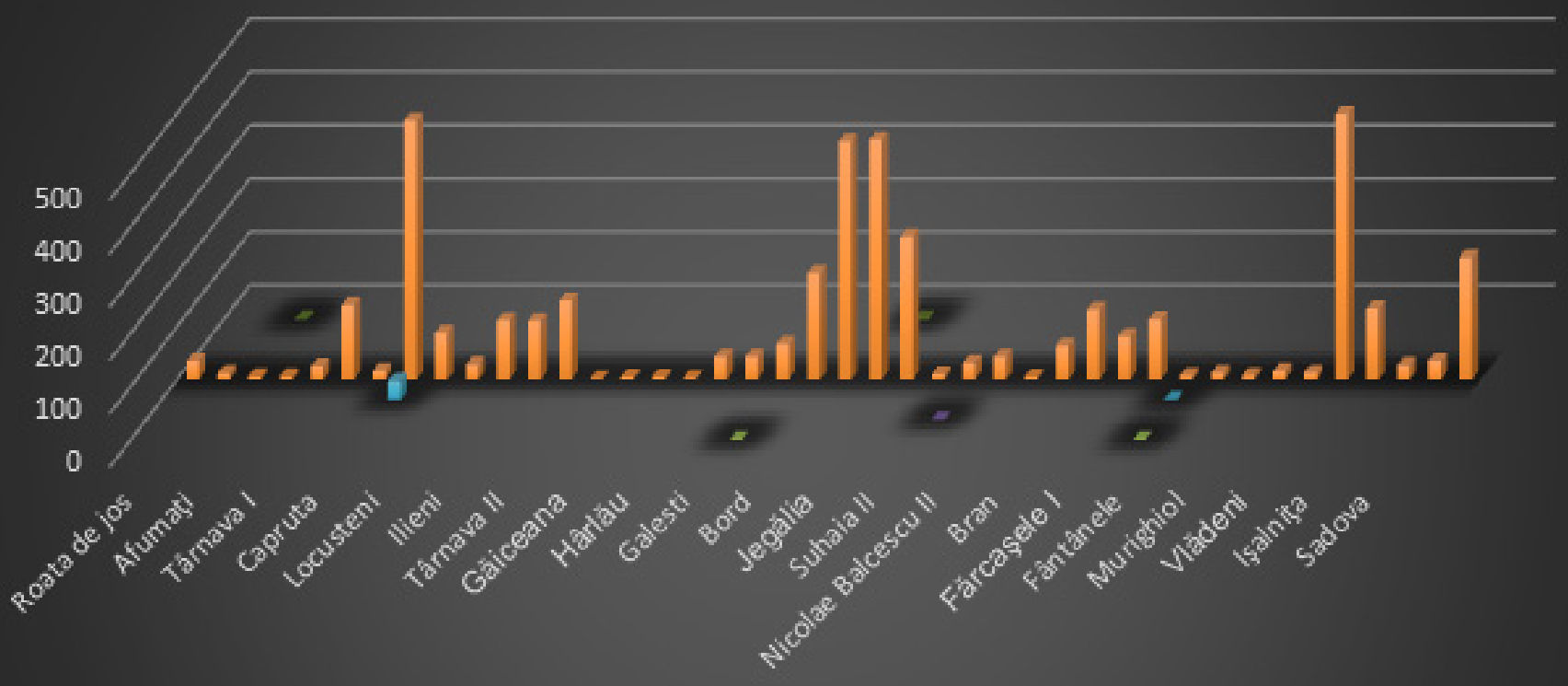

$\begin{array}{lll}\text { nDr. Apollonia } & \text { Dr. Dyrrachium } & \text { Tdr. Macedonia Prima } \\ \square \text { Tdr. Thasos } & \text { nenar } & \text { - Copies of Dr. Apollonia } \\ \text { - Copies of Dr. Dyrrachium } & \text { nCopies of Tdr. Thasos } & \text { - Copies of Denar }\end{array}$

Figure 5. Coin hoards with Roman Republican denarii and mix hoards from 50/41BC according to Table 2.

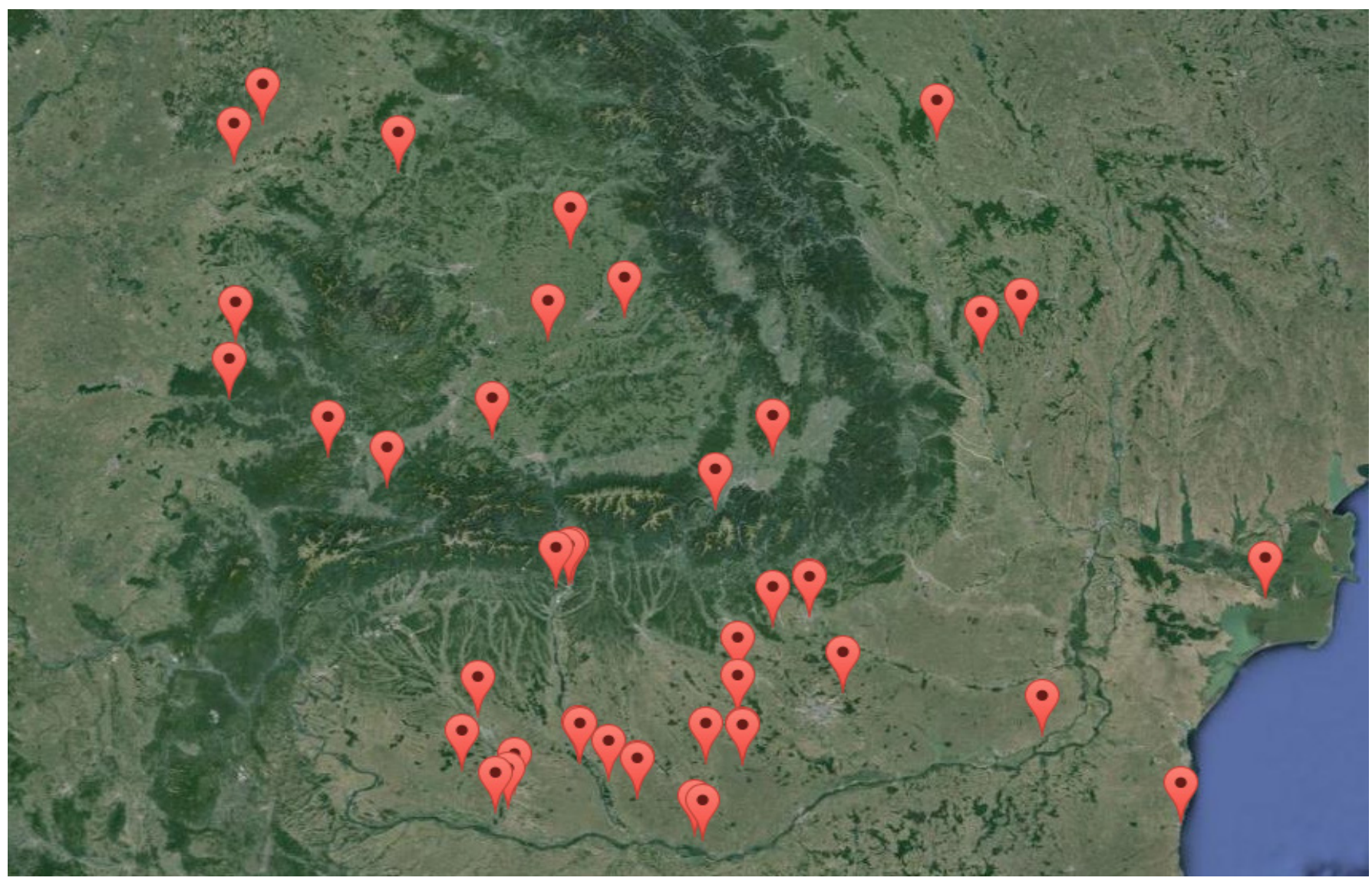

Map 4: The map of coin hoardss from 50/41 BC in Romania.93

93 http://tezauremonetare.ro/maps?utf8=\%E2\%9C\%93\&q\%5Blocation cont $\% 5 \mathrm{D}=\& \mathrm{q} \% 5 \mathrm{Bperiod}$ cont $\% 5 \mathrm{D}=50 \% 2 \mathrm{~F} 41 \& \mathrm{q} \% 5 \mathrm{~B}$ province cont $\% 5 \mathrm{D}=\&$ q $\% 5$ Broad true $\% 5 \mathrm{D}=0 \& \mathrm{q} \% 5 \mathrm{Broad}$ false $\% 5 \mathrm{D}=0$ \& commit $=$ Search
MONETARY HOARDS FROM THE YEARS 59/52

BC

In Figure 4, the horizontal axis represents the names of the cities where the hoards were found and the vertical axis represents the number of each type of coin from the hoard. 
According to this figure, it is possible to state that once the hoards became fewer they also consist of low number of coins. Obviously, it is important to find an historical event or sources that could confirm this fact. An explanation could be that the Third Mithidratic War or the foundation of the Dacian state, which forced the locals to hoard coins. Specific events such like those mentioned, could affect the supply pattern also in Dacia.

As difficult as it is to observe the entry moment for the Roman Republican denarius in Dacia, it is not the same to observe the moment when the denarius became very strong in Dacia. According to Figure 2, between 50/41 BC the number of hoards reached the highest level, coinciding wirh the period in which mix hoards slowly disappear from Dacia. Not only the mix hoards disappeared but also the coins of Greek cities. (Figure 5)

\section{MONETARY HOARDS FROM 50/41 BC}

In the Figure 5 the horizontal axis represents the name of the localities where the hoard was found as well as the year when the hoard closed, and the vertical axis represents the number of each type of coin found in the hoard.

The period 50/41 BC is thought to be by most researchers the moment when the Roman Republican denarius was imposed in the Geto-Dacian space. Everybody of these researchers has their own opinion regarding the reason why the denarius reached Dacia and what was its function in the Geto-Dacian society. This period coincides with the Civil War between 49 - 45 BC. According to Crawford's theory, in this period the number of coins grows. ${ }^{94}$ For the same period, it is possible to see the moment according to the Figure 2.
The number of coin hoards with Roman Republican denarii decreases, and the hoards with mix coins start to disappear from the Geto-Dacian area.

According to Map 4, it can be noticed that between 50 and 41 BC the denarius not only imposed in Dacia, but also spread across a larger geographical area, especially around the rivers that could be used as commercial means of transportation.

The period between 40 and $31 \mathrm{BC}$ is the interval when, as shown in Figure 2, the number of Roman Republican denarii decreases significantly. This period is known in the history of Rome as being very tumultuous until the naming of Octavian as the new August. There were the wars between Octavian and Marcus Antononius (41 - 40 BC and 32 - 30 $\mathrm{BC}$ ) and the Sicilian Revolt (44 - 35 BC), between the second Triumvirate and Sextus Pompeius, the son of Pompeius.

Details on the coin hoards from the Geto-Dacic space between 40 and 31 BC can be seen on Figure 6 and their distribution on Map 5.

\section{MONETARY HOARDS FROM 40/31 BC}

In Figure 6 the horizontal axis represents the names of the cities where the hoard was found as well as the year that hoard closes and the vertical axis represents the number of each type of coin found in the hoard.

The entry of the Roman Republican denarius in Dacia

According to Graph 2, the Roman Republican denarius can be found in hoards ever since $90 / 81$ BC, thus raising the question whether this could be the temporal interval that the Roman Republican denarius enters Dacia. From the data presented in the graphic, it is possible to say that this period

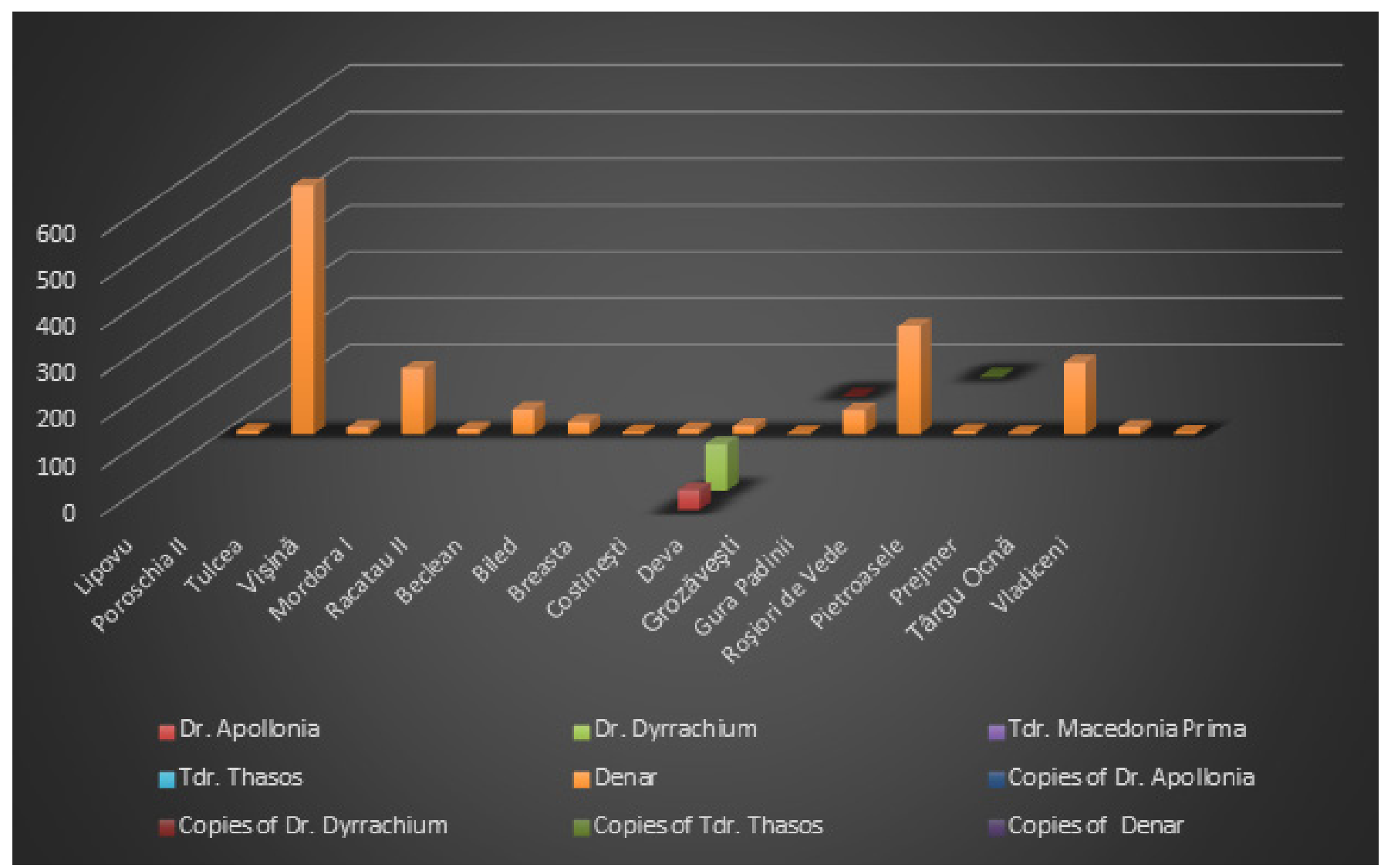

Figure 6. Coin hoards with Roman Republican denarii and mix hoards from 40/31 BC.

94 CRAWFORD 1969, 79. 
Studies

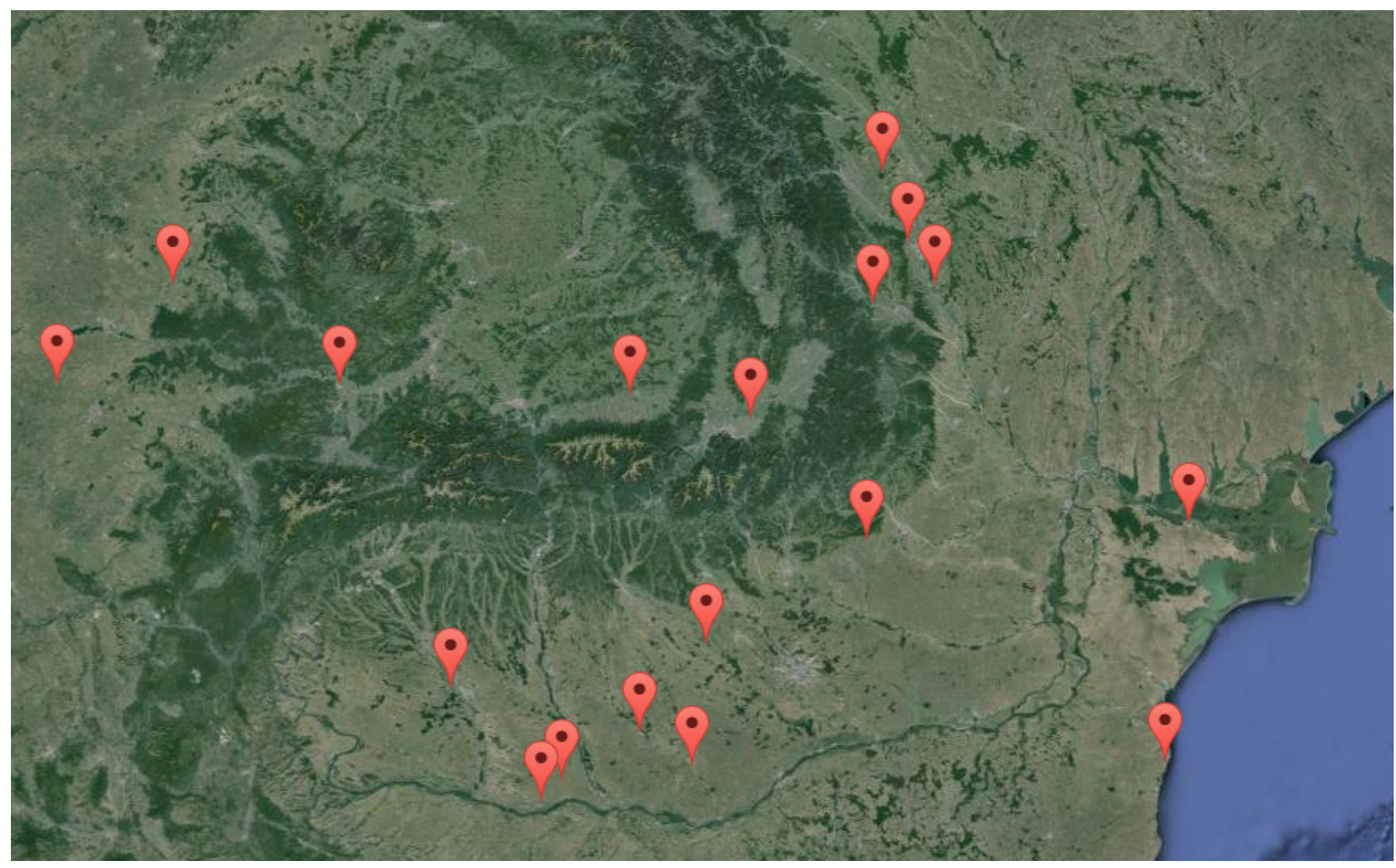

Map 5. The map with coin hoards from 40/31 BC in Romania. ${ }^{95}$

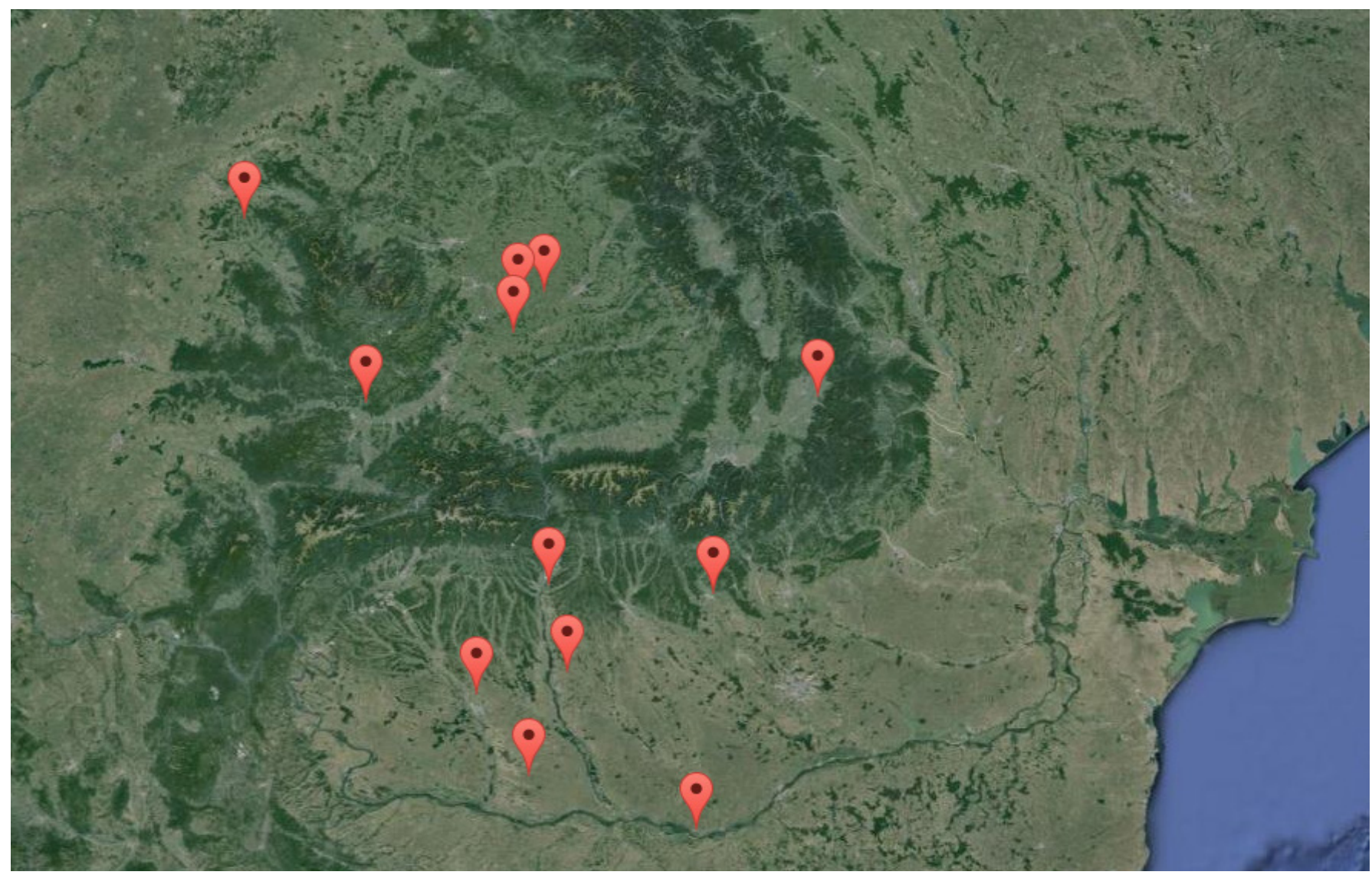

Map 6: Map with coin hoards from 90/81 BC in Romania. ${ }^{96}$

95 http://tezauremonetare.ro/maps?utf8=\%E2\%9C\% $93 \& q \% 5$ Blocation cont $\% 5 \mathrm{D}=\& \mathrm{q} \% 5 \mathrm{Bperiod}$ cont $\% 5 \mathrm{D}=40 \% 2 \mathrm{~F} 31 \& \mathrm{q} \% 5 \mathrm{~B}$ province cont $\% 5 \mathrm{D}=\& \mathrm{q} \% 5 \mathrm{Broad}$ true $\% 5 \mathrm{D}=0 \& \mathrm{q} \% 5 \mathrm{Broad}$ false $\% 5 \mathrm{D}=0$ \&commit=Search

96 http://tezauremonetare.ro/maps?utf8=\%E2\%9C\%93\&q\%5Blocation cont $\% 5 \mathrm{D}=\& \mathrm{q} \% 5 \mathrm{Bperiod}$ cont $\% 5 \mathrm{D}=90 \% 2 \mathrm{~F} 81 \& \mathrm{q} \% 5 \mathrm{~B}$ province cont $\% 5 \mathrm{D}=\&$ q $\% 5$ Broad_true $\% 5 \mathrm{D}=0 \&$ q $\% 5$ Broad false $\% 5 \mathrm{D}=0 \&$ commit $=$ Search 


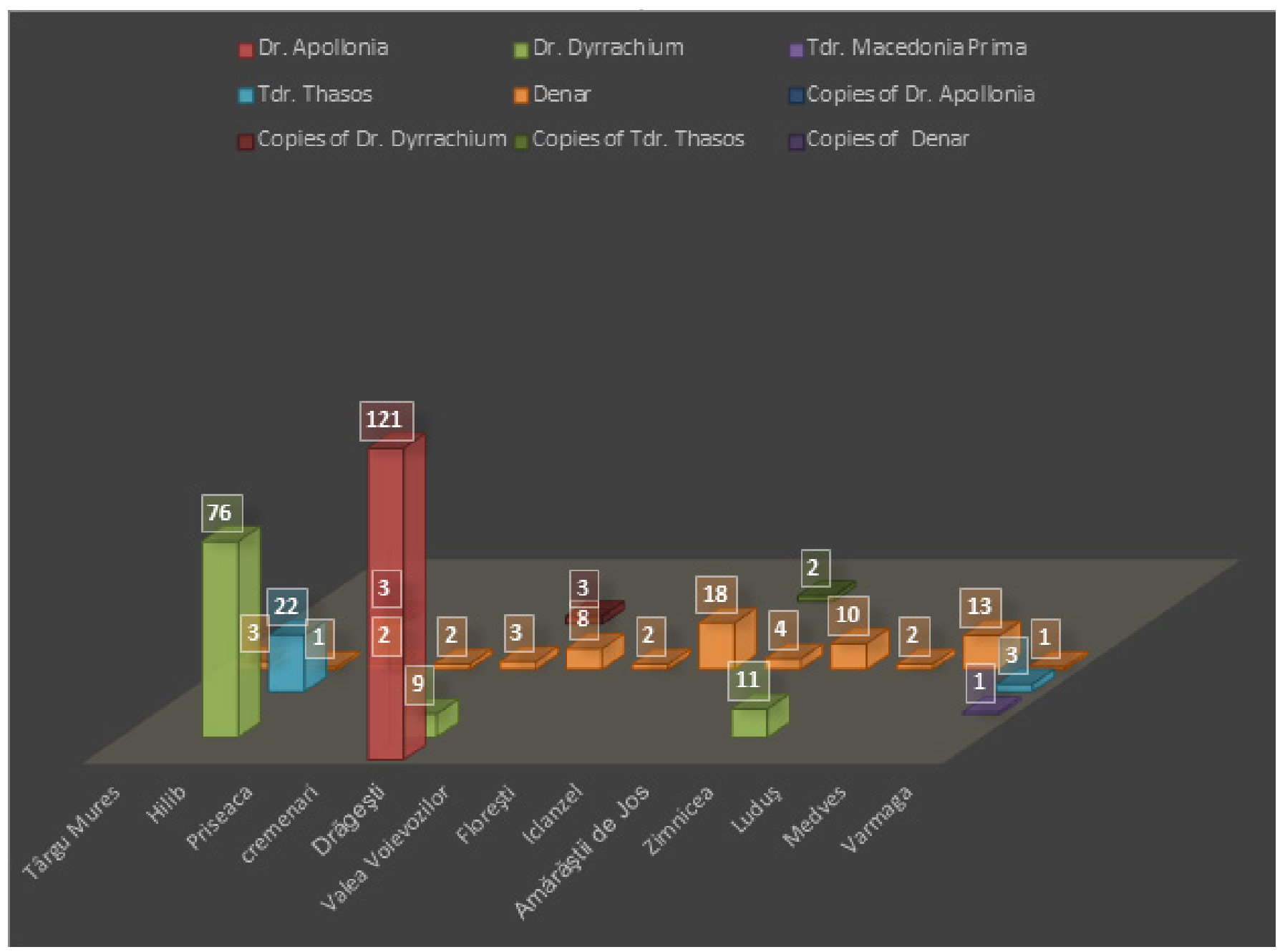

Figure 7. Coin hoards with Roman Republican denarii and mix hoards from 90/81 BC.

could be the period in which Geto-Dacian populations were accustomed with the coin (Map 6).

It is important to remember that the information resulted from the graphic must be passed through an objective filter in order to be verified. Thus, for a more objective result, it is recommended to observe what happened in 90/81 $\mathrm{BC}$ from an historical point of view. The most important historical event of this interval is the Social War 90-88 BC. According to M. Crawford, the number of coins tends to increase during periods with important political-military events or social events. ${ }^{97}$ In consequence, it is possible to say that the coins closing the hoards found in the interval 90/81 $\mathrm{BC}$ are not from that period because, as M. Crawford stated, coins can circulate for a long time and can be found closing hoards 20, 30 years later, thus generating confusion among researchers. Thus, the interval $90 / 80 \mathrm{BC}$ is highly unlikely to be the moment the denarius enters Dacia, even though it can be statistically verified (Figure 7).

\section{MONETARY HOARDS FROM 90/81 BC}

In Figure 7, the horizontal axis represents the name of each city were hoards were found as well as the year each hoard closes.

Based on Table 2, a graph was build (Figure 8) that shows the percentage situation of the Roman Republican denarii in the coin hoards from the $1^{\text {st }}$ century $B C$ on the 97 CRAWFORD 1969, 78. territory of Romania.

According to this table, the period 80/71 BC seems to be the moment when the denarius appears in important quantities in hoards. Since it has been agreed that the period 90/81 BC cannot be taken into consideration, the present study will not focus on it.

From what results from some analysis of hoards from $80 / 71 \mathrm{BC}$, the hoards from Romania resemble with the ones found in Italy ${ }^{98}$. Thus, it is possible to say that according to the Graph 8 and after analyzing hoards from $80 / 71$ BC, that period is the most likely the period when the coin entered the Geto-Dacian area. The focus will now shift on the segment 80/71 BC.

Based on Map 7 can be seen that already in this temporal interval there are distributed on a large geographical area, where Geto-Dacian unfolded their economic activity, hoards that Roman Republican denarii. According to Figure 2, this period coincides with the first growth of the coin hoards with Roman Republican denarii. The composition of the hoard from 80/71 BC will be presented in Figure 9.

According to information provided by Glodariu, the coin hoards are concentrated in areas with intense commercial activities. ${ }^{99}$

98 LOCKYEAR 1996, 389

99 GLODARIU 1976, 180. 
Studies

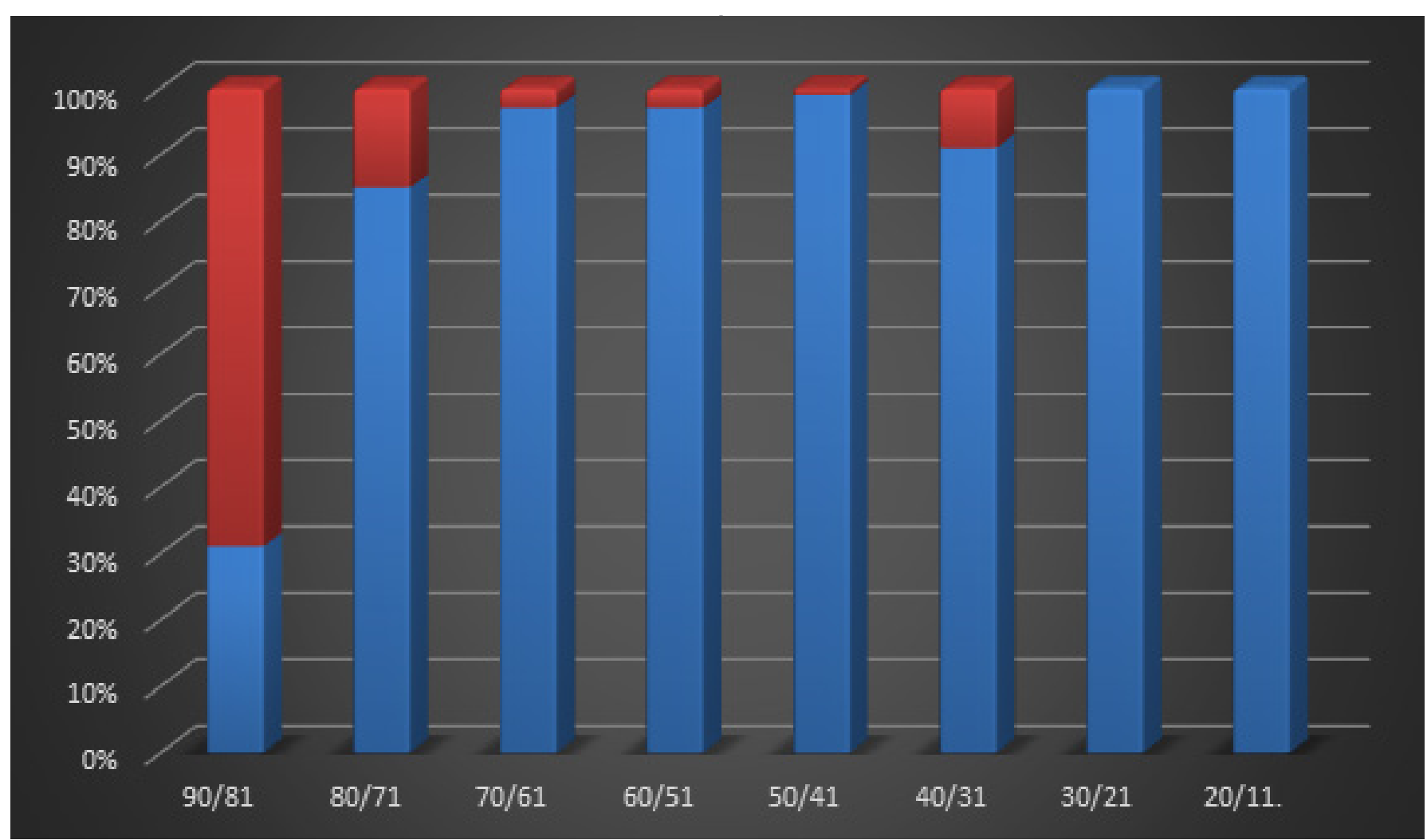

Figure 8: The percentage of denarii in the coin hoards presented in Table 2.

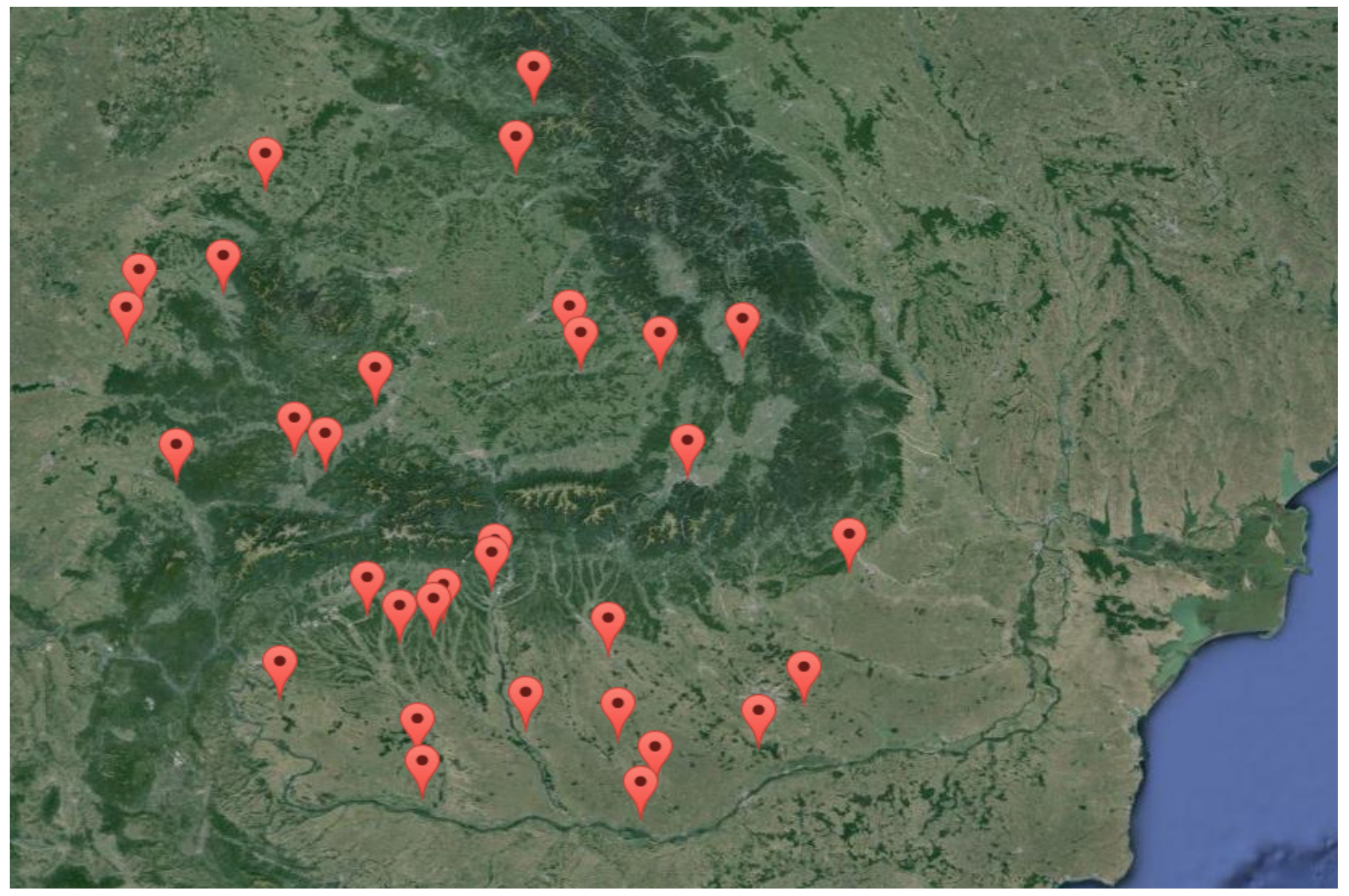

Map 7. The map with coin hoards from 80/71 BC. ${ }^{100}$

100 http://tezauremonetare.ro/maps?utf8=\%E2\%9C\%93\&q\%5Blocation cont $\% 5 \mathrm{D}=\& \mathrm{q} \% 5 \mathrm{Bperiod}$ cont $\% 5 \mathrm{D}=80 \% 2 \mathrm{~F} 71 \& \mathrm{q} \% 5 \mathrm{~B}$ province cont $\% 5 \mathrm{D}=\& \mathrm{q} \% 5 \mathrm{Broad}$ true $\% 5 \mathrm{D}=0 \& \mathrm{q} \% 5 \mathrm{Broad}$ false $\% 5 \mathrm{D}=0 \&$ commit $=$ Search

\section{MONETARY HOARDS FROM 80/71 BC}

In Figure 9, the horizontal axis represents the name of each city where the hoards were found as well as the closing year for each hoard. The vertical axis represents the 


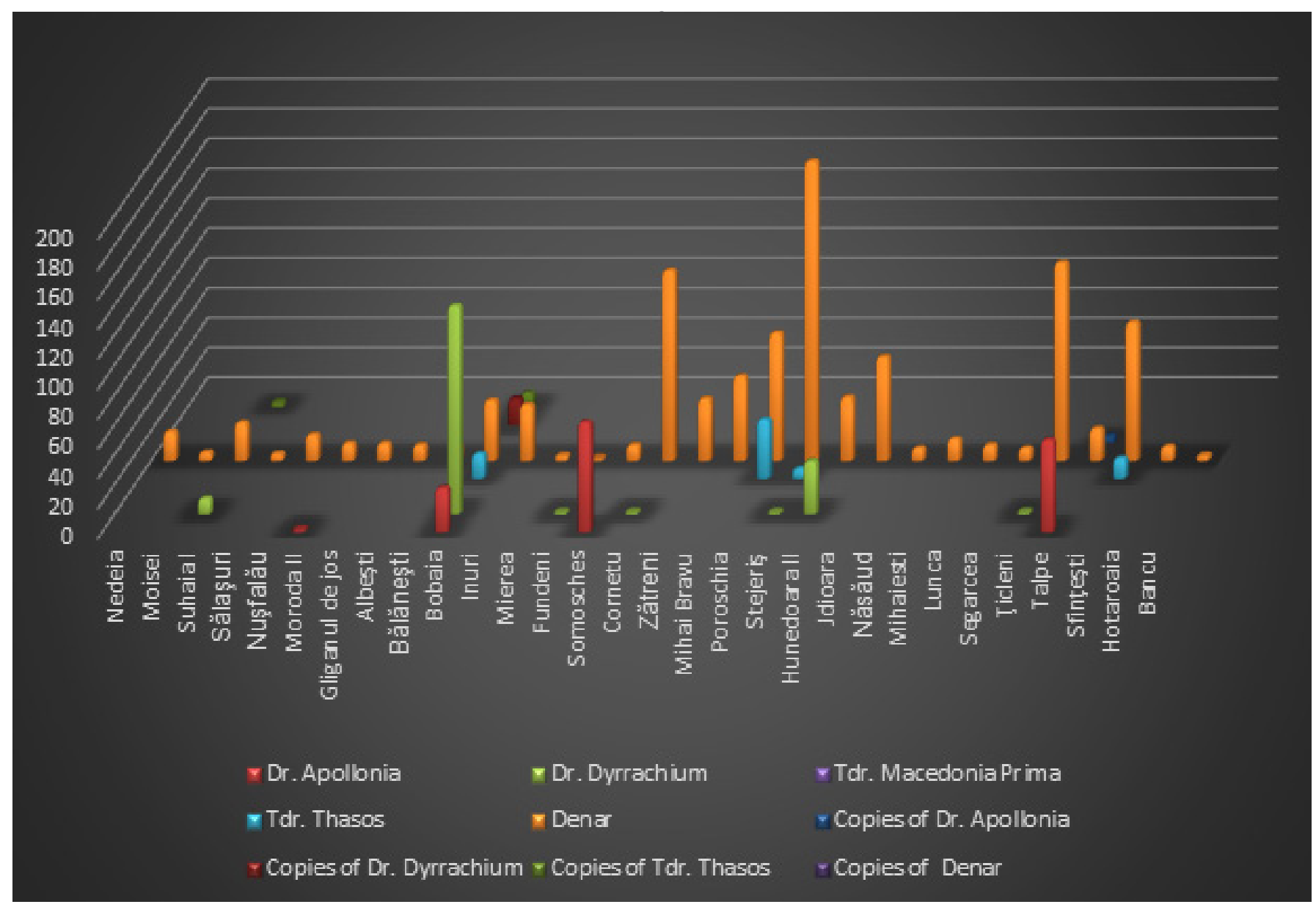

Figure 9. Coin hoards cu Roman Republican denarii and mix coin hoards 80/71 BC according to Table 2.

number of each type of coin found in the hoards.

Thus, according to this graph, the period 80/71 BC was the moment the Roman Republican denarius becomes more consistent in coin hoards. This fact is easy to notice also from the Graphic 8, where can be observed the percentile composition of the denarius in the hoards. Considering all these, it is possible to say that the moment when the denarius entered Dacia is somewhere between 80/71 BC.

The reasons why denarii enter the Geto-Dacian space are many. The main reasons are commercial relations between the Hellenistic and the Geto-Dacian world, the relations being known since antiquity. ${ }^{101}$ Polybius claims that from the area of the Black Sea the following goods were exported to the Greek cities and the Greco-Roman world: cattle, honey, wood, slaves, wax, fish, wood, and the elites of the populations of the Black Sea imported wine, olive oil, generally luxury goods. All this information is confirmed by I. Glodariu who brings archaeological evidence, demonstrating the high volume of trade between the Geto-Dacian world and the Hellenistic world or the Greco-Roman one. ${ }^{102}$

Both the Roman and the Greek coinages can be set within this frame of trade environment. Due to geographical location of the Geto-Dacians, in close proximity to the Hellenistic world, it is possible to say that trade relations were intense. Therefore, Roman and Greek merchants bought from the area only raw materials, which were, generally speaking, expensive. This may explain the large number of

101 Polybius IV.38.3-7.

102 GLODARIU 1976, 8 silver coins with small denominations found in the hoards. It is possible that the Geto-Dacian populations have kept the coins to be used in trade with merchants coming from the Greco-Roman world, which means that they were not only bartering. Another reason for keeping silver would be the cultural one.

The entry of the Roman Republican denarii in Dacia, after a long period of contact with the Hellenistic world, can be regarded simply as a continuation of commercial activities Dacians had with the Hellenistic world, where the Romans make their presence felt. It is well-known the fact that locals imitated the coins of the Greek cities in circulation. The presence of the denarius must be seen in a wider context, the half of the $1^{\text {st }}$ century $\mathrm{BC}$ is the moment when the Roman world gets involved very strongly in the trade of the Hellenistic world. In the same key can be viewed and imitations denarius, which may be a continuation of the phenomenon known since before Roman Republican denarii entry in Dacia. It is well known that the locals imitated Greek cities coins in circulation. The presence of denarii be seen in a wider context, mid-century BC when the Roman world is 'invading' the Hellenistic world trade.

Indeed, in the aftermath of the pirates' annihilation by Pompeius in $67 \mathrm{BC}$, the Romans got very involved in the trade area. The need for slaves after some internal problems in the Italian peninsula, such as the Revolt of Spartacus (74 $\mathrm{BC}$ ) and the capturing of slaves by pirates, forced the Romans to import slaves from other areas right before Pompeius's intervention in $67 \mathrm{BC}$. Hypothetically, it is possible that the 
area where the Geto-Dacian populations was an important source for slave ${ }^{103}$. The massive import of slaves from Dacia can be explained by hoards dated 50/41 BC, when most of the hoards with Roman Republican denarii are documented.

The Romans imposed their coinage in the Mediterranean and Pontic world due to their military and technical-naval superiority but also because of the diplomatic ways.

Tacitus offer us a piece of information, about the behavior of Germanic population when they get in touch with the Roman coinage. This information can be used in analogy for the Dacian population: "Pecuniam probant veterem et diu notam, serratos bigatosque. Argentum quoque, magis quam aurum sequuntur, nulla affectione animi, sed quia numerus argenteorum facilior usui est promiscua ac vilia mercantibus." ${ }^{104}$

Tacitus wrote this paragraph in the second half of the $1^{\text {st }}$ century $\mathrm{AD}$. In the text, he refers to the Germanic populations, which were all bordering the Mediterranean world and which preferred old good silver/gold currencies as a consequence of the fiscal reform of Nero in 54-68 BC. This coincides with the moment when less silver was used for manufacturing denarii. Owing to these aspects, the Germanic populations demanded the old coins, the ones used before the fiscal reform.

It is worth mentioning here, that the serrated denarii (serratos) - mentioned by Tacitus - were also found in the republican hoards found in Dacia. Thus, another case when such a coin is discovered on a territory beyond the Roman frontier that has trade relations with the Greco-Roman world. One can easily notice a similar pattern for two civilizations connected to the Roman world.

\section{CONCLUSIONS}

Following this research, it can be concluded that the moment when the Roman Republican denarii entered Dacia may not be find out with accuracy. The information offered by the coin hoards is not offering clear evidence

From the statistic research performed, the time segment 80/71 BC, most likely, represents this moment.

Beside this aspect, a set of interesting questions can be raised on this occasion:

a) Why the local populations wanted to have Roman Republican denarius?

b) What was the function these coins had in the GetoDacian society?

c) Why were the imitations made and why they made them so faithful?

d) Which was the role these coins played in the transactions that occurred in this geographical area in the late Iron Age?

In order to answer to the first two questions, it is necessary to get back to (Map 7) and (Figure 9) and conclude that the emergence of the Roman Republican denarii is mainly due to economic activities. Thus, the denarius has an economic function, and the population want to use it for trade with the merchants coming from the Greco-Roman world. It is very unlikely that the denarius was used as an internal means of economic exchange, because there are no smaller

103 CRAWFORD 1977, 118

104 Tacitus, Germania, V.3. denominations of the denarius present in the Geto-Dacian area $^{105}$. The Roman coinage system which begin during the Second Punic War, consisted essentially of bronze unit, the as, with a set of smaller denominations in bronze, and of a silver unit, the denarius, with a set of smaller denominations in silver ${ }^{106}$. In the course of the second century B.C., the value of the bronze coinage fell in relation to the silver coinage. ${ }^{107}$

The last two questions require a different study than the one discussed in this paper. To determine why imitations were made or what role denarii played in the social transformations that occurred in this area, we need more than statistic studies. Anthropological analysis should be carried on for observing the social of the Dacians. One reason why locals imitated denarii might just be a continuation of the phenomenon of imitating coins from Greek cities. Therefore, it must be observed why did locals imitate coins and not mint their own currency. The problem is complicated also by the coin-dies found in the Dacian area. Imitations were made perfectly, very difficult to track down. The question is then, why were the denarii so faithfully imitated and tetradrachmas and drachmas not. Was it just an evolution in the copying technique? It is very unlikely, because there are not known any notable technical developments in the Geto-Dacian area at that time. The question remains open because, at the moment, there are no sources that could offer an answer. An answer may be suggested by the interpretation of the archaeological evidence.

\section{REFERENCES:}

\section{AUSTIN 2006}

Austin, M.M., The Hellenistic World from Alexander to the Roman Conquest. A Selection of Ancient Sources in Translation BABES, 1975 (Cambridge University Press).

Babeş $\mathrm{M}$,, Problèmes de la chronologie de la culture géto-dace a la lumiére des fouilles de Cârlomăneşti, Dacia, N. S. 19, 125-139.

CRAWFORD 1969

Crawford, M.H., Coin hoards and the pattern of violence in the late Republic, Papers of the British School in Rome 37, 1969, 76-81.

CRAWFORD 1970

Crawford, M.H., Money and exchange in the roman world, Journal of Roman Studies 60, 40-48.

CRAWFORD 1974

Crawford, M.H., Roman Republican Coinage (Cambridge: Cambridge University Press).

\section{CRAWFORD 1977}

Crawford, M.H., Republican denarii in Romania: the suppression of piracy and the slave-trade, Journal of Roman Studies 67, 117-124.

\section{CRIȘAN 1979}

Crișan, I. H., Premisele întemeierii statului dac centralizat și independent condus de Burebista, Sargetia 14, 59-69

CRIȘAN 1979

Crișan, I. H., Statul dac centralizat și independent condus de Burebista, Acta Musei Porolissensis 3, 103-119.

CHIȚESCU 1971

Chițescu, M., Câteva tezaure romane republicane descoperite în Moldova, Carpica 4, 159-166.

105 CRAWFORD 1977, 118

106 CRAWFORD 1970, 40.

107 CRAWFORD 1970, 40. 


\section{CHIȚESCU 1980}

Chițescu, M., Les monnaies géto-daces de type romain républicain et impérial, Dialogues d'Histoire ancienne 6, 123138.

\section{CHIȚESCU 1981}

Chitescu, M., Numismatic Aspects of the Dacian State [British Archaeological Reports, Oxford, International series 112] (Oxford: Archaeopress).

DAICOVICIU 1972

Daicoviciu, C., Die Dako-Geten. Eine Richtigstellung. In: $I^{\text {er }}$ Congrès International de Thracologie. Contribution roumaine (Sofia: Academie bulgare des sciences), 67-75.

DALTON 1965

Dalton, G., Primitive money, American Anthropologist 67, 44-65.

FINLEY 1985

Finley, M.I., The ancient Economy (London: Hoarth Press).

GLODARIU 1976

Glodariu, I., Dacian Trade with the Hellenistic and Roman World [British Archaeological Reports, Supplementary Se-

HARRIS 2008 ries 8] (Oxford: Archaeopress)

Harris, W.V., The Late Republic. In: Scheidel, W./Morris, I./ Saller, R.P. (eds.), The Cambridge Economic History of the Greco-Roman World (Cambridge: Cambridge University Press), 511-542.

HOWGEGO 1994

Howgego, Ch., Coin circulation and integration of the Roman economy, Journal of Roman Archaeology 7, 5-21.

HOWGEGO 1995

Howgego, Ch., Ancient History from Coins (London - New York: Routledge), $2^{\text {nd }}$ ed.

HOLLANDER 2007

Hollander, D.B., Money in the late Roman Republic [Columbia Studies in the Classical Tradition 29] (Leiden - Boston: Brill).

LUPU 1967

Lupu, N., Aspekte des Münzumlaufs im vorrömischen Daka ien, Jahrbuch für Numismatik und Geldgeschichte 17, 101121

LOCKYEAR 1996

Lockyear, K., Multivariate Money. A statistical analysis of Roman Republican coin hoards with special reference to material from Romania (PhD thesis, University of London).

LOCKYEAR 1997

Lockyear, K., The supply of Roman Republican denarii to Romania, Studii şi Cercetări de Numismatică 11, 85-102.

\section{LOCKYEAR 1999}

Lockyear, K., Hoard Structure and Coin Production in An- tiquity - an Empirical Investigation, Numismatic Chronicle 159, 215-243.

LOCKYEAR 2007

Lockyear, K., Pattern and Process in Roman Republican Coin Hoards [British Archaeological Reports, Oxford, International series 1733] (Oxford: Archaeopress).

LOCKYEAR 2008

Lockyear, K., Aspects of Roman Republican coins found in Late Iron Age Dacia. In: Spinei, V./Munteanu, L. (eds.), Miscellanea numismatica Antiquitatis. In honorem septagenarii magistri Virgilii Mihăilescu-Bîrliba oblata (București: Editura Academiei Române), 147-176.

MIHĂILESCU-BÎRLIBA 1990

Mihăilescu-Bîrliba, V., Dacia răsăriteană în secolele VI-I î. e.n. Economie și monedă (Iaşi: Junimea).

MITREA 1958

Mitrea, B., Legături comerciale ale geto-dacilor din Muntenia cu Republica Romana reflectate în descoperiri monea tare, Studii si Cercetări de Numismatică 2, 151-166.

MOISIL/DEPEYROT 2003

Moisil, D./Depeyrot, G., Les Trésors de Deniers Antérieurs à Trajan en Roumanie [Collection Moneta 33] (Wetteren: Moneta).

POENARU-BORDEA/COJOCĂRESCU 1984

Poenaru-Bordea, Gh./Cojocărescu, M., Contributii la circulația monetară din centrul Transilvaniei în secolul I î.e.n. tezaurul monetar descoperit la Icland (com. Ernei, jud. Mures), Studii şi Cercetări de Numismatică 8, 53-75.

PREDA 1973

Preda, C., Monedele geto-dacilor [Biblioteca de Arheologie 19] (Bucuresti: Editura Academiei Republicii Socialiste România0.

PREDA 1998

Preda, C., Istoria monedei în Dacia preromană [Colecţia "Biblioteca Băncii Naţionale" 25] (București: Editura Enciclopedică).

ROUGE 1966

Rouge, J., Recherches sur l'organisation du commerce maritime en Méditerranée sous l'Empire romain (Paris: S.E.V.P.E.N)

SYDENHAM 1952

Sydenham, E.A., The Coinage of the Roman Republic (London: Spink).

WINKLER 1955

Winkler, I., Contributii numismatice la istoria Daciei, Studii si Cercetări Științifice Cluj 1-2, 13-180. 